2. To: (Receiving Organization)

High-Level Waste Interim Storage

5. Proj./Prog./Dept./Div.:

TWRS/Environmental/Environme ntal Permit \& Policy

8. Originator Remarks:

Document submitted for approval and release.

11. Receiver Remarks

11A. Design Baseline Document?
[] Yes [X] No

[] Yes $[X]$ No

3. From: (Originating Organization)

TWRS Environmental Permit \& Pol icy

6. Design Authority/ Design Agent/Cog.

C. A. Petersen
4. Related EDT No.:

605602

7. Purchase Order No.

$N / A$

9. Equip./Component No.: $\mathrm{N} / \mathrm{A}$

10. System/Bldg./Facility: CSB

12. Major Assm. Dwg. No.: $\mathrm{N} / \mathrm{A}$

13. Permit/Permit Application No. $\mathrm{N} / \mathrm{A}$

14. Required Response Date: $4 / 1 / 97$

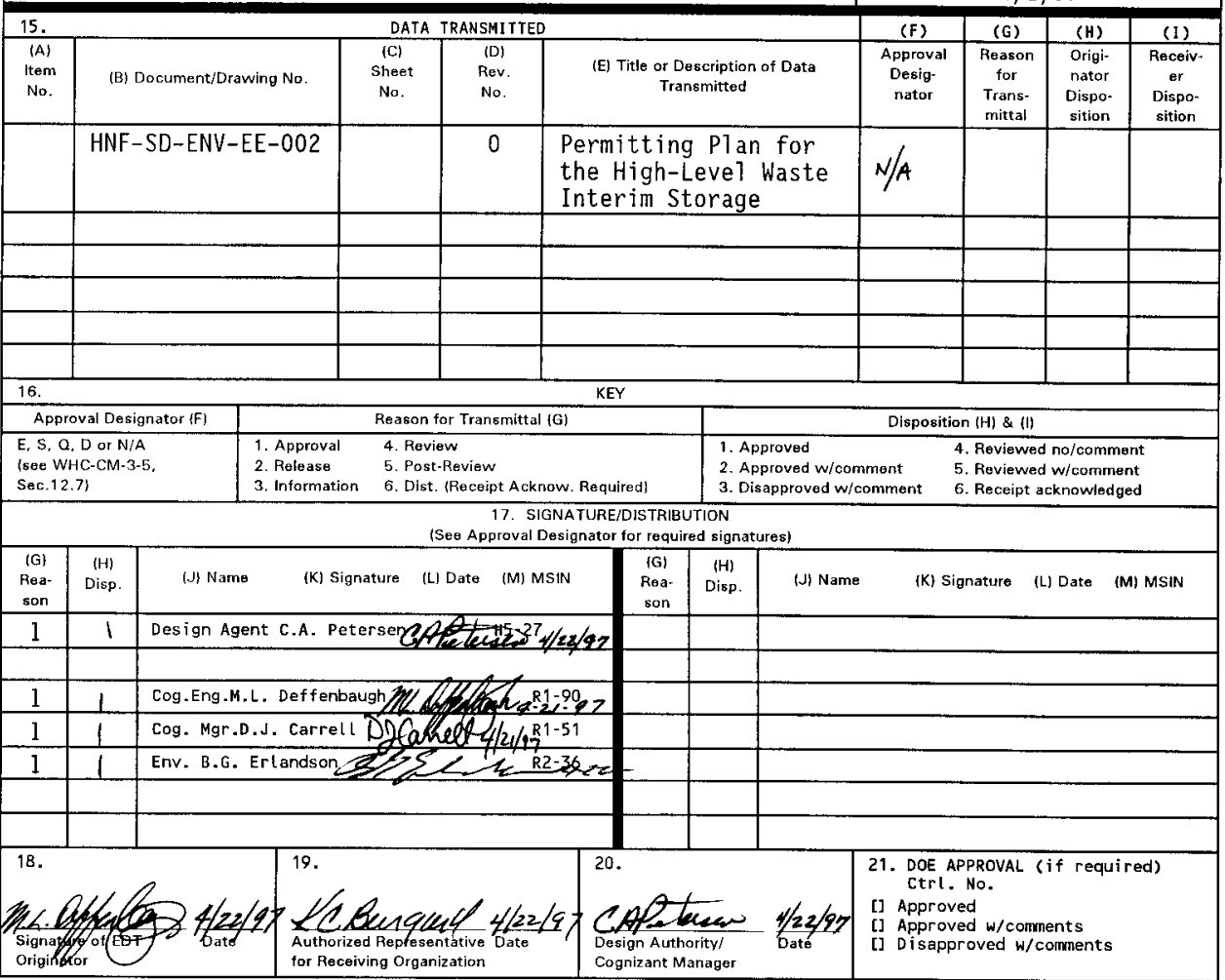

BD -7400-172-2 (05/96) GEF097 


\title{
Permitting Plan for the High-Level Waste Interim Storage
}

\author{
M.L. Deffenbaugh \\ Lockheed Martin Hanford Corporation, Richland, WA 99352 \\ U.S. Department of Energy Contract DE-AC06-96RL13200
}
EDT/ECN: $\quad$ EDT-605602
UC: 2030
Org Code: 70311
B\&R Code: EW3130010
Charge Code: D4NK1
Total Pages: 58

Key Words: National Environmental Policy Act (NEPA), State Environmental Policy Act (SEPA), Resource Conservation Recovery Act (RCRA), Radiation Protection and Standards

Abstract: Permitting Plan regarding NEPA, SEPA, and RCRA standards, and drafting permitting strategy, cost, transforation, and alternatives. Plan lists standards for radioactive and non-radioactive emissions.

TRADEMARK DISCLAIMER. Reference herein to any specific comercial product, process, or service by trade name, trademark, manufacturer, or otherwise, does not necessarily constitute or imply its endorsement, recommendation, or favoring by the United States Government or any agency thereof or $i$ ts contractors or subcontractors.

Printed in the United States of America. To obtain copies of this document, contact: Document Control Services, P.O. Box 950, Mailstop H6-08, Richtand WA 99352, Phone (509) 372-2420;
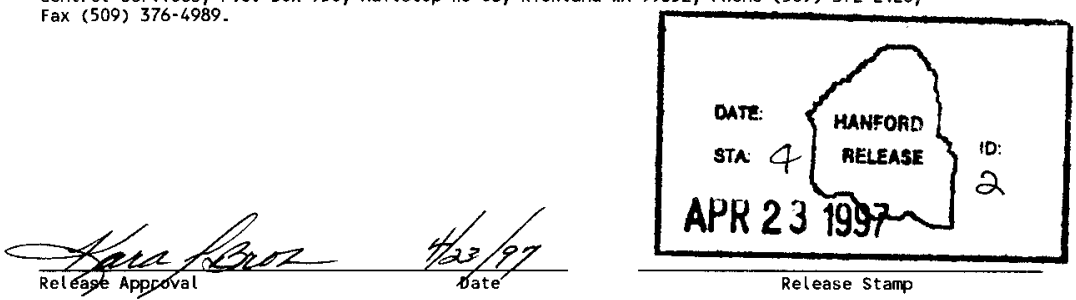


\title{
Permitting Plan for the High-Level Waste Interim Storage Project
}

\author{
M. L. Deffenbaugh \\ J. D. Guberski \\ C. J. Grando \\ K. A. Elsethagen \\ V. L. Armstrong \\ Lockheed Martin Hanford Corporation
}

J. E. Mercado

Rust Federal Services Northwest

Date Published

April 1997

Prepared for the U.S. Department of Energy

Assistant Secretary for Environmental Management

Project Hanford Management Contractor for the

U.S. Department of Energy under Contract DE-AC06-96RL13200

Approved for public release; distribution is unlimited 
HNF-SD-ENV-EE-002 Rev. 0

\section{CONTENTS}

1.0 INTRODUCTION $\ldots \ldots \ldots \ldots \ldots \ldots \ldots \ldots \ldots \ldots \ldots \ldots \ldots \ldots \ldots \ldots \ldots$

2.0 NATIONAL ENVIRONMENTAL POLICY ACT $\ldots \ldots \ldots \ldots \ldots \ldots \ldots . . \ldots \ldots$

2.1 INTRODUCTION . . . . . . . . . . . . . . . . 2-1

2.2 SUMMARY OF DATA AND/OR INFORMATION REQUIREMENTS . . . 2-1

2.3 DISCUSSION OF ALTERNATIVES . . . . . . . . . . . . . 2-2

2.4 RECOMMENDED NATIONAL ENVIRONMENTAL POLICY ACT

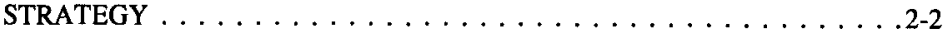

2.5 PRELIMINARY COST ESTIMATE $\ldots \ldots \ldots \ldots \ldots \ldots \ldots \ldots .2-3$

3.0 WASHINGTON STATE ENVIRONMENTAL POLICY ACT . . . . . . . . 3-1

3.1 INTRODUCTION . . . . . . . . . . . . . . . . 3-1

3.2 SUMMARY OF DATA AND/OR INFORMATION $\ldots \ldots \ldots \ldots \ldots .3-1$

3.3 DISCUSSION OF ALTERNATIVES . . . . . . . . . . . . . 3-1

3.4 RECOMMENDED WASHINGTION STATE ENVIRONMENTAL

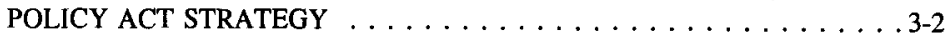

3.5 PRELIMINARY COST ESTIMATE $\ldots \ldots \ldots \ldots \ldots \ldots \ldots$. . . . . . . .

4.0 RESOURCE CONSERVATION AND RECOVERY ACT $\ldots \ldots \ldots \ldots \ldots . . .4$. . . . .

4.1 INTRODUCTION $\ldots \ldots \ldots \ldots \ldots \ldots \ldots \ldots \ldots \ldots \ldots . \ldots \ldots$ 4-1

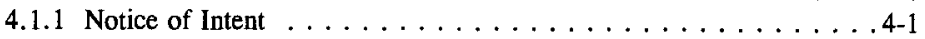

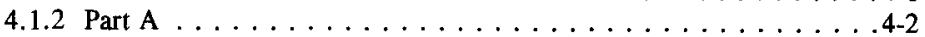

4.1 .3 Part B . . . . . . . . . . . . . . 4-2

4.1.4 Listing Exclusion . . . . . . . . . . . . . 4-3

4.2 SUMMARY OF DATA/INFORMATION REQUIREMENTS . . . . . . . . 4-4

4.2.1 Notice of Intent and Part A . . . . . . . . . . . . 4-4

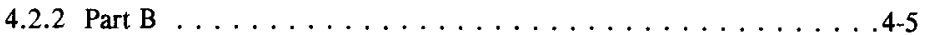

4.3 DISCUSSION OF ALTERNATIVES . . . . . . . . . . . . . . 4-7

4.4 RECOMMENDED PERMITTING STRATEGY . . . . . . . . . . . 4-9

4.5 PRELIMINARY COST ESTIMATE . . . . . . . . . . . . . . 4-9

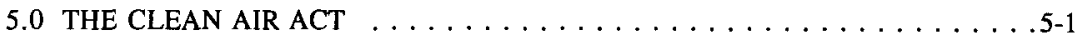

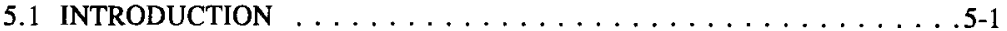

5.2 SUMMARY OF DATA/INFORMATION REQUIREMENTS $\ldots \ldots \ldots \ldots$. . .

5.3 DISCUSSION OF ALTERNATIVES . . . . . . . . . . . . . . 5-1

5.4 RECOMMENDED PERMITTING STRATEGY $\ldots \ldots \ldots \ldots \ldots \ldots$. . . . .

5.5 PRELIMINARY COST ESTIMATE $\ldots \ldots \ldots \ldots \ldots \ldots \ldots$. $\ldots \ldots$ 
HNF-SD-ENV-EE-002 Rev. 0

CONTENTS (Continued)

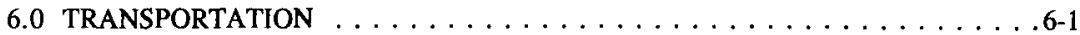

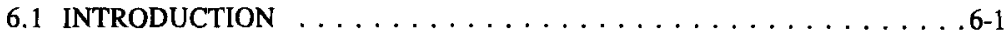

6.2 SUMMARY OF DATA/INFORMATION REQUIREMENTS . . . . . . . . 6-1

6.3 DISCUSSION OF ALTERNATIVES . . . . . . . . . . . . 6-2

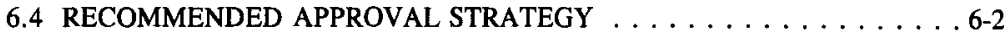

6.5 PRELIMINARY COST ESTIMATE $\ldots \ldots \ldots \ldots \ldots \ldots \ldots \ldots$. . . . . .

7.0 RADIATION PROTECTION STANDARDS/MONITORING $\ldots \ldots \ldots \ldots \ldots$ 7-1

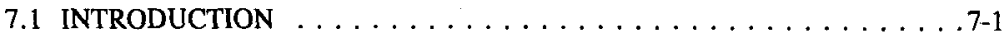

7.2 SUMMARY OF DATA OF INFORMATION REQUIREMENTS $\ldots \ldots \ldots 7-1$

7.3 DISCUSSION OF ALTERNATIVES . . . . . . . . . . . . . 7-1

7.4 RECOMMENDED STRATEGY . . . . . . . . . . . 7-2

7.5 PRELIMINARY COST ESTIMATE $\ldots \ldots \ldots \ldots \ldots \ldots \ldots \ldots$. . $\ldots \ldots$

8.0 REFERENCES $\ldots \ldots \ldots \ldots \ldots \ldots \ldots \ldots \ldots \ldots \ldots \ldots \ldots . \ldots \ldots \ldots$

\section{APPENDIXES}

APPENDIX A: HIGH-LEVEL WASTE INTERIM STORAGE

PERMITTING PLAN COST AND SCHEDULE $\ldots \ldots \ldots \ldots \ldots$ A-1

APPENDIX B: ENVIRONMENTAL REQUIREMENTS CHECKLIST FOR THE HIGH-LEVEL WASTE STORAGE PROJECT

CANISTER STORAGE BUILDING $\ldots \ldots \ldots \ldots \ldots \ldots \ldots$ B-1 


\section{LIST OF TERMS}

CSB

CFR

CWC

DOE

DOE-RL

DOT

DST

Ecology

EIS

EPA

FEIS

HLRW

HLW

HLWIS

HWVP

IHLW

ILAW

NEPA

NOD

$\mathrm{NOI}$

NRC

PHMC

RCRA

ROD

SEPA

SNF

TPA

TSD

TWRS

WAC
Canister Storage Building

Code of Federal Regulations

Central Waste Complex

U.S. Department of Energy

U.S. Department of Energy, Richland Operations Office

U.S. Department of Transportation

double-shell tank

Washington State Department of Ecology

environmental impact statement

U.S. Environmental Protection Agency

Final Environmental Impact Statement

high-level radioactive waste

high-level waste

high-level waste interim storage

Hanford Waste Vitrification Plant

Immobilized High-Level Tank Waste

Immobilized Low-Activity Tank Waste

National Environmental Policy Act of 1969

Notice of Deficiency

Notice of Intent

Nuclear Regulatory Commission

Project Hanford Management Contractor

Resource Conservation and Recovery Act of 1976

Record of Decision

State Environmental Policy Act of 1971

Spent Nuclear Fuel

Tri-Party Agreement (Hanford Federal Facility Agreement and

Consent Order)

treatment, storage, and/or disposal

Tank Waste Remediation Systems

Washington Administrative Code 
HNF-SD-ENV-EE-002 Rev. 0

This page intentionally left blank. 


\section{PERMITTING PLAN FOR THE HIGH-LEVEL WASTE INTERIM STORAGE PROJECT}

\subsection{INTRODUCTION}

This document addresses the environmental permitting requirements for the transportation and interim storage of solidified high-level waste (HLW) produced during Phase 1 of the Hanford Site privatization effort. Solidified HLW consists of canisters containing vitrified HLW (glass) and containers that hold cesium separated during low-level waste pretreatment.

The glass canisters and cesium containers will be transported to the Canister Storage Building (CSB) in a U.S. Department of Energy (DOE)-provided transportation cask via dieselpowered tractor/trailer.

Tri-Party Agreement (TPA) Milestone M-90 establishes a new major milestone, and associated interim milestones and target dates, governing acquisition and/or modification of facilities necessary for: 1) interim storage of Tank Waste Remediation Systems (TWRS) immobilized HLW (IHLW) and other canistered high-level waste forms; and 2) interim storage and disposal of TWRS immobilized low-activity tank waste (ILAW).

An environmental requirements checklist and narrative was developed to identify the permitting path forward for the HLW interim storage (HLWIS) project (See Appendix B). This permitting plan will follow the permitting logic developed in that checklist. 
HNF-SD-ENV-EE-002 Rev. 0

This page intentionally left blank. 


\subsection{NATIONAL ENVIRONMENTAL POLICY ACT}

The National Environmental Policy Act of 1969 (NEPA) (42 USC 4321, et seq.), was enacted to ensure that environmental matters are considered before federal actions are initiated that might affect the quality of the human environment. The DOE regulation [10 Code of Federal Regulations (CFR) 1021] promulgated under NEPA was developed to conform with 40 CFR 1500-1508 regulations and to categorize the environmental impacts associated with various DOE proposals or actions.

\subsection{INTRODUCTION}

The proposed action to store HLW canisters by improving the existing vaults in the Canister Storage Building is a major action requiring appropriate NEPA documentation.

\subsection{SUMMARY OF DATA AND/OR INFORMATION REQUIREMENTS}

The types of information and data needed can be grouped into the following broad categories:

- Purpose and Need for Action

- Why action is needed now and how it relates to other actions.

- Alternatives Considered

- Do nothing different from current storage, pick a disposal method that does not require intermediate storage, use a different type or form of interim waste storage, or use a different location for interim storage.

- Environments and Resources Affected

- Geological, aquatic, atmospheric, biological, cultural, socioeconomic, terrestrial, visual, audio, and natural environments; transportation resources.

- Environmental Consequences

- Possible consequences to environments listed above. Also, anticipated health affects from routine and non-routine operations, including accidents. Possibility of disproportionate impacts on minority group(s) must be identified. 
HNF-SD-ENV-EE-002 Rev. 0

- Statutory and Regulatory Requirements

- These relate to Resource Conservation and Recovery Act of 1976 (RCRA) and other permitting requirements addressed in other sections of this permitting plan.

Preparation of appropriate NEPA documentation requires data on: natural, biological, or cultural resources used or impacted by the alternatives considered; socioeconomics of the region; land use, both current and future; visual resources impacted; noise and transportation impacts from construction, operation, and decommissioning; and hazardous or toxic substances used or potentially released into the environment.

\subsection{DISCUSSION OF ALTERNATIVES}

Four alternatives exist for NEPA documentation regarding the action to store HLW canisters in the CSB:

1. Prepare an environmental impact statement (EIS).

2. Prepare an environmental assessment to determine if an EIS is needed or if a finding of no significant impact is appropriate.

3. Identify that the action to be taken is covered by an existing EIS.

4. Prepare a supplement to an appropriate existing EIS so that it generally addresses the action to be taken. The supplement would discuss alternatives or impacts not discussed or bounded by the existing EIS. A possible means of doing this is to use the existing Final Environmental Impact Statement: Management of Spent Nuclear Fuel from the $K$-Basins at the Hanford Site, Richland, Washington, DOE/EIS-0245-F, U.S. Department of Energy, Washington, D.C. (DOE 1996a).

\subsection{RECOMMENDED NATIONAL ENVIRONMENTAL POLICY ACT STRATEGY}

Adhere to the U. S. Department of Energy's Record Of Decision (ROD), [62 FR 8693] for the Tank Waste Remediation System. The ROD was based upon the Final Environmental Impact Statement for the Tank Waste Remediation System, DOE/EIS-0189F (DOE 1996b), authored by the U.S. Department of Energy and the Washington State Department of Ecology (Ecology).

The "Phased Implementation Alternative," was identified in the final EIS as the preferred alternative. The pertinent items listed within the ROD are: 
- Storing separated HLW at the treatment facilities or in the Canister Storage Building pending future HLW treatment

- Transporting the low- and high-activity wastes to onsite interim storage facilities

- $\quad$ Packaging the HLW in canisters for onsite interim storage and future shipment to a national geologic repository, and placing the immobilized low-activity waste in containers and placing the containers in onsite, near-surface disposal facilities.

\subsection{PRELIMINARY COST ESTIMATE}

(See Appendix A) 
HNF-SD-ENV-EE-002 Rev. 0

This page intentionally left blank. 


\subsection{STATE ENVIRONMENTAL POLICY ACT}

The State Environmental Policy Act of 1971 (SEPA) (Chapter 43.21C Revised Code of Washington) legislation is the Washington State equivalent of NEPA, and requires evaluation of environmental impacts associated with a project or an agency action before approval of the project or action is granted. The SEPA rules, Washington Administrative Code (WAC) Chapter 197-11 (WAC 197-11), are the implementing regulations.

\subsection{INTRODUCTION}

The normal method of addressing the SEPA requirements is to complete a SEPA checklist that provides the information necessary for the appropriate State agency to make a threshold determination on the significance of the proposed action. If the proposed action is categorically exempt or non-significant, further action under SEPA is not required. If the proposed action is significant, preparation of an environmental impact statement is required. An option exists for adoption of an existing document(s) (e.g., a NEPA EIS) to fulfil the agency's responsibilities.

\subsection{SUMMARY OF DATA AND/OR INFORMATION}

The types of data and information needed are those discussed in Section 2.2 regarding the NEPA process.

\subsection{DISCUSSION OF ALTERNATIVES}

Three alternatives exist for compliance with SEPA:

1. Submit a SEPA checklist in conjunction with an application for permit(s) needed(e.g., air, RCRA, building) and let the agency determine if an environmental impact statement is required.

2. Submit a letter to, or provide a briefing to, appropriate regulatory agencies (Ecology is normally the lead agency for TWRS activities) stating that the U.S. Department of Energy, Richland Operations Office (DOE-RL) believes an environmental impact statement is required.

3. Submit a letter to, or provide a briefing to, appropriate regulatory agencies (Ecology is normally the lead agency for TWRS activities) stating that DOE-RL believes that existing environmental documentation provided to or prepared by Washington State agencies, and issuance of permits by those agencies, cover this action. 
HNF-SD-ENV-EE-002 Rev. 0

\subsection{RECOMMENDED STATE ENVIRONMENTAL POLICY ACT STRATEGY}

The recommended approach is to inform Ecology that the Tank Waste Remediation Systems/Final Environmental Impact Statement (TWRS/FEIS) (DOE 1996b), the Spent Nuclear Fuels FEIS (DOE 1996c), and issuance of permits necessary for construction of the Canister Storage Building cover this action. This could be included in the notice of intent to expand the capacity of the canister storage building regarding RCRA permitting (See Section 4.3).

\subsection{PRELIMINARY COST ESTIMATE}

(See Appendix A) 


\subsection{RESOURCE CONSERVATION AND RECOVERY ACT}

RCRA was enacted as a comprehensive national program to mandate that hazardous waste will be treated, stored and disposed of so as to minimize the present and future threat to human health and the environment. In the State of Washington, the dangerous waste regulations (WAC 173-303) are the implementing regulations.

\subsection{INTRODUCTION}

The Canister Storage Building will store HLW that has been treated by vitrification. Vitrification was identified by the U.S. Environmental Protection Agency (EPA) as the best demonstrated available technology for the hazardous characteristics of corrosivity and toxicity associated high-level waste, and were promulgated in the Federal Register on June 1, 1990. Treatment of high-level waste with vitrification process, however, does not address HLW that is or was derived from a listed hazardous waste. The vitrified HLW will be a listed waste because it was derived from double-shell tank (DST) waste, which is a listed hazardous waste. Therefore, vitrified high-level waste is still subject to RCRA requirements because the waste was considered hazardous by listing prior to treatment.

So that a non-dangerous waste can be provided to the off-site repository, the immobilized HLW must receive a listing exclusion from the EPA (40 CFR 261.22). This 'delisting' of the waste will allow the immobilized high level waste to exit RCRA and State of Washington dangerous waste regulations.

Because the process for obtaining this 'delisting' is dependent on actions to be taken with the private contractors, the scope of the activity is uncertain. In order to provide the greatest likelihood of success for storing immobilized HLW on the schedule outlined in the Tri-Party Agreement, TWRS Environmental is proposing to obtain a RCRA permit for storage of immobilized HLW while concurrently working with the EPA to obtain a listing exclusion for the waste.

An application for a treatment, storage and/or disposal (TSD) facility permit consists of three collective submittals. Each submittal consists of various levels of detailed information concerning the facility. The three submittals are the Notice of Intent (NOI), the Part A, Form 3 permit application (Part A), and the Part B permit application (Part B).

The dangerous waste regulations (WAC 173-303) apply to all facilities within Washington State that treat, store, and/or dispose of dangerous waste. These regulations are equivalent to, or more stringent than, the federal hazardous waste regulations. Under the dangerous waste program, all TSD facilities must obtain a permit. Facilities that were in existence on November 19, 1980, were granted an interim status permit with the submittal of a Part A identifying the intent to treat, store and/or dispose of dangerous waste. Interim status ends 
after final administrative disposition of the Part B documentation is completed, and a final status permit is granted or denied.

Refer to Appendix A for the RCRA HLWIS CSB permitting schedule.

\subsubsection{Notice of Intent}

An NOI is required for proposed facilities or expansion at an existing facility. Expansion includes enlargement of land surface area, the addition of new dangerous waste processes, or an increase in overall design capacity. The NOI contains preliminary information concerning the proposed facility and/or expansion. The NOI requires a general process description, operating capacities, waste type, a topographic map, and a statement of environmental conditions, and could include a SEPA environmental checklist.

In accordance with WAC 173-303-281, the NOI must be submitted to the public (public reading rooms), Ecology, and the EPA, Region 10. A public notification is published in a local daily newspaper for 14 consecutive days. The NOI process normally requires approximately 11 months to complete and submit.

\subsubsection{Part A}

The Part A includes process design capacity, process description, dangerous waste numbers and estimated annual quantity, description of dangerous waste, facility diagrams, photographs, geographic location, facility owner, and operator/co-operator certification. The Part $A$ is submitted no earlier than 150 days following submittal of the NOI to Ecology and the public. The preparation process requires approximately 6 months to complete, including DOE-RL/Project Hanford Management Contractor (PHMC) review and certification.

\subsubsection{Part B}

The Part B provides detailed descriptions of the design, operation and maintenance, training, contingency planning, closure, and other relevant information concerning the waste management facility.

The Part $\mathrm{B}$ is evaluated by the regulating agencies for completeness and technical adequacy. The latter includes plausibility, general detail of plans and procedures, and protection of human health and the environment. For any item deemed incomplete or technically inadequate, Ecology issues a notice of deficiency (NOD) to the applicant. Resolution of NODs and subsequent modification of the Part B permit application is through an informal workshop process that involves the DOE-RL, PHMC, and Ecology. 
When satisfied with the Part B, Ecology prepares a draft permit. The draft permit enforces permit provisions and may reference sections of the final Part B. This draft permit is published for public and interagency review. Upon completion of the public review period, significant public comments are factored into the final status permit issued by Ecology. For the Hanford Site, one dangerous waste permit has been issued for the Hanford Facility. Upon completion of the unit-specific Part B process, each unit will be appended to the Hanford Facility Dangerous Waste Permit. Generally, preparation of a Part B requires approximately 14 months through the first certification cycle, and the total duration may last approximately 3 to 6 years.

Interim status expansion may be requested from Ecology and the U.S. EPA. Once the revised Part A and NOI are submitted, construction can proceed if Ecology and EPA grant interim status expansion under the Part A.

\subsubsection{Listing Exclusion}

The administrative process to petition the EPA to amend 40 CFR Part 261 to exclude a waste (i.e., delisting) is contained in 40 CFR 260.20 and 40 CFR 260.22. The administrative process includes: a petition by DOE of EPA to modify or amend 40 CFR 261; EPA evalution of the petition; EPA publication of its tentative decision in the Federal Register, and issuance of a request for public comment; EPA evaluation of the public comments; and EPA arrival at a final decision. EPA publishes its final decision in the Federal Register and, if the petition is approved, will issue a regulatory amendment. Successful petitions to amend 40 CFR 261 can be found in 40 CFR 261, Appendix IX, Table 1.

In order to be successful, the petitioner must:

- Demonstrate to the satisfaction of the EPA that the immobilized HLW produced by the private vendor does not meet any of the criteria under which the waste was listed as a hazardous or acutely hazardous waste.

(40 CFR 260.22(a)). The demonstration must be made with respect to the waste mixture as a whole, and must apply to a specific waste generated at a specific facility and stored in a specific unit. (40 CFR 260.22(b))

- Conduct analyses not only for those constituents for which the listed waste contained in the mixture was listed, but also for other factors (including additional constituents) that could cause the waste mixture to be a hazardous waste. (40 CFR 260.22(b))

- Provide extensive information regarding the process that generated the waste (40 CFR 260.22(i))

- Provide extensive information regarding the laboratory and analytical methods used (40 CFR 260.22(i)). 
The EPA can request any additional information which they may reasonably require in order to evaluate the petition.

The unique data required by the PHMC for the petition are highly dependent on the information that can be obtained from the private contractors, who are required by contract to comply with the land disposal restrictions (40 CFR 268). The analytical data and testing of product required for this delisting petition appear to be redundant to these requirements. Definitive estimates of scope, schedule, and resources cannot be developed until these redundancies are explored. Significant cost and schedule savings can occur if data developed by the private contractors, used to demonstrate compliance with the land disposal restrictions, can be used for the delisting petition.

\subsection{SUMMARY OF DATA/INFORMATION REQUIREMENTS}

Following is a summary of the information required for the RCRA permit documentation under WAC 173-303, "Dangerous Waste Regulations."

\subsubsection{Notice of Intent and Part A}

The following information is required under WAC 173-303-281, -282 and -805 when submitting an NOI for expansion under interim status:

- Facility description

- Explanation of expansion

- Siting criteria

- 10-year summary of compliance violations at the Hanford Facility

- Demonstrated need for expansion

- Comparison of proposed expansion to overall unit capacity

- A SEPA environmental checklist

- 150-day public review of NOI prior to filing the Part A

- A TPA milestone M-20 submittal for submittal of the initial Part B

- Negotiation with Ecology for submittal of the final Part B into the Hanford Facility RCRA permit. 


\subsubsection{Part B}

Following are general requirements for the Part B. These requirements are not considered all inclusive.

- A general description of the facility

- Chemical, biological, and physical analyses of the dangerous waste and hazardous debris to be handled at the facility. At a minimum, these analyses must contain all the information which must be known to treat, store or dispose of the wastes properly in accordance with WAC 173-303-600.

- A copy of the waste analysis plan required by WAC 173-303-300(5)

- A description of security procedures and equipment required by WAC 173303-310, or a justification demonstrating the reasons for requesting a waiver of this requirement

- A copy of the general inspection schedule required by WAC 173-303-320(2) and 173-303-630(6)

- A description of the procedures used to comply with the preparedness and prevention requirements of WAC 173-303-340, or a justification of any request for a waiver(s) from these requirements

- A copy of the contingency plan required by WAC 173-303-350

- A description of the procedures, structures, or equipment used at the facility to:

- Prevent hazards and contain spills in unloading/loading operations

- $\quad$ Prevent runoff from dangerous waste handling areas to other areas of the facility or environment, or to prevent flooding

- $\quad$ Prevent contamination of water supplies

- $\quad$ Mitigate effects of equipment failure and power outages

- $\quad$ Prevent undue exposure of personnel to dangerous waste

- Prevent releases to the atmosphere.

- Vehicular traffic pattern, estimated volume, and control 
- Seismic risk consideration. The owner or operator must identify the seismic risk zone in which the facility is intended to be located. It must be demonstrated that the facility is designed to resist seismic ground motion and that the design is sufficient to withstand the maximum horizontal acceleration of a design earthquake specified in the demonstration.

- An outline of both the introductory and continuing training programs that prepare persons to operate or maintain the TSD facility in a safe manner as required to demonstrate compliance with WAC 173-303-330. A brief description of how training will be designed to meet actual job tasks in accordance with the requirements in WAC 173-303-330(1)(d).

- A copy of the closure plan required by WAC 173-303-610(3) and 173-303630(10)

- A topographic map meeting all applicable requirements in WAC 173-303806(4)(a)(xviii).

\section{Specific Container Requirements}

- A description of the containment system to demonstrate compliance with WAC 173-303-630(7). Show at least:

- Basic design parameters, dimensions, and materials of construction, including allowance for a 25-year, 24-hour storm

- How the design promotes positive drainage control or how containers are kept from contact with standing liquids in the containment system

Capacity of the containment system relative to the volume of the largest container to be stored

- $\quad$ Provisions for preventing or managing run-on

- How accumulated liquids can be analyzed and removed to prevent overflow

- A description of the building or other protective covering for extremely hazardous waste containers.

- For storage areas that store containers holding wastes that do not contain free liquids, a demonstration of compliance with WAC 173-303-630(7)(c), including: 
- Test procedures and results or other documentation or information to show that the wastes do not contain free liquids

A description of how the storage area is designed or operated to drain and remove liquids or how containers are kept from contact with standing liquids

- A description of procedures for labeling containers.

\subsection{DISCUSSION OF ALTERNATIVES}

The alternatives for permitting HLW canister storage are discussed below. The probability of success (High, Medium, Low) will follow each listed alternative.

1. Submit an NOI for expansion under interim status (adding a new unit to the Hanford facility RCRA permit) and submit a new Part A and Part B. (High)

Assumptions:

a) An NOI will be submitted to increase the overall design capacity for canister storage.

b) New Part A and Part B permit applications will be written and submitted.

c) The Hanford Facility RCRA permit will be modified to include the new Part B permit application schedule. DOE/RL-91-28, General

Information Portion (DOE-RL 1991), will also require modification.

2. Modify the existing Hanford Waste Vitrification Plant (HWVP) Part A, and submit an NOI for expansion. Write a new Part B permit application. (High)

Assumptions:

a) The HWVP Part A will be modified by separating out vitrified waste canister storage at the CSB into its own Part A. Dangerous waste codes may be affected.

b) An NOI will be submitted to increase the overall design capacity for storage of vitrified waste in canisters at the CSB.

c) A new Part B permit application will be written and submitted. 
d) The Hanford Facility RCRA permit will be modified to include the new Part B permit application schedule. DOE/RL-91-28, General

Information Portion (DOE-RL 1991), will also require modification.

3. Modify the Central Waste Complex (CWC) Part A and Part B Permit, and submit an NOI for expansion (the CWC will receive their final status permit in 1998). (Low)

Assumptions:

a) An NOI will be submitted for an increase in overall design capacity.

b) The CWC Part A modification will be submitted and will include addition of canister storage of vitrified waste in the CSB. The modification is unlikely to affect dangerous waste codes.

c) The CWC Part B Permit will be modified (WAC 173-303-830 Class III Modification).

d) The Hanford Facility RCRA permit will be modified, including DOE/RL-91-28, General Information Portion (DOE-RL 1991).

4. Modify DST Part A and Part B permits, and submit an NOI for expansion (the DST system will receive their final status permit in 1999). (Low)

Assumptions:

a) An NOI will be submitted for addition of a new waste management process.

b) The DST Part A will be submitted, and will include addition of canister storage of vitrified waste in the CSB. Dangerous waste codes will be affected.

c) The DST system Part B permit will be modified (WAC 173-303-830 Class III Modification).

d) The Hanford Facility RCRA permit will be modified. DOE/RL-91-28, General Information Portion (DOE-RL 1991), will also require modification. 


\subsection{RECOMMENDED PERMITTING STRATEGY}

The recommended permitting strategy for the HLW CSB is alternative \#2. Negotiation with Ecology and EPA of TPA milestones for achieving final status prior to beginning CSB retrofitting may be required. Under interim status, hot operation of the CSB may begin without a final status permit. However, this issue is subject to negotiation with Ecology.

So that this task can be performed in the most cost effective manner, the scope of a delisting petition needs to be better defined. The Hanford Site has experience in delisting, and this experience can be tapped to better define this work. TWRS Environmental proposes to perform (or contract for) an evaluation of delisting requirements. After this evaluation is complete, and the scope is better defined, discussions with the private contractors could be initiated. These discussions would center on identifying the data each contractor will be providing to demonstrate compliance with LDR, and evaluating the most effective way to obtain the balance of the information needed for the petition.

\subsection{PRELIMINARY COST ESTIMATE}

(See Appendix A). 
HNF-SD-ENV-EE-002 Rev. 0

\subsection{THE CLEAN AIR ACT}

The Federal Clean Air Act of 1970 (42 USC 7401 et seq.) was enacted in 1970, amended in 1977, and overhauled and expanded in 1990.

\subsection{INTRODUCTION}

Solidified HLW, planned for interim storage in Vaults 2 and 3 of the CSB, is to be produced as part of the privatization effort to immobilize tank waste. A detailed review of the facility design, the storage process, the physical form of the emission sources, and regulatory requirements concluded that the CSB will not be a source of regulated emissions to the atmosphere. The solidified waste will be in the form of vitrified HLW and cesium. The cesium will result from low-level waste pre-treatment operations. Primary containment of the vitrified waste will be provided by hermetically sealed stainless steel canisters. Primary containment of the cesium will be provided by hermetically sealed stainless containers. Each canister/container will have been evacuated, sealed, decontaminated and surveyed before being transferred to the CSB.

Because these containment methods are used, no requirement exists for permitting the CSB under federal/State regulations.

\subsection{SUMMARY OF DATA/INFORMATION REQUIREMENTS}

This conclusion was based on a detailed review of the project design criteria and State and federal regulatory requirements.

\subsection{DISCUSSION OF ALTERNATIVES}

No alternatives are needed.

\subsection{RECOMMENDED PERMITTING STRATEGY}

Confirmation from the Washington State Departments of Health and Ecology that the hermetically sealed canisters/containers do not constitute a source of regulated emissions will be obtained from each State agency in writing.

\subsection{PRELIMINARY COST ESTIMATE}

(See Appendix A) 
HNF-SD-ENV-EE-002 Rev. 0

This page intentionally left blank. 


\subsection{TRANSPORTATION}

The transportation of radioactive materials within Hanford Site boundaries in areas that are not accessible to the public is not currently subject to U.S. Department of Transportation (DOT) regulation. Transportation and packaging operations are authorized and controlled by contractor-approved procedures and safety evaluations.

\subsection{INTRODUCTION}

The mechanism by which the transportation and packaging of radioactive materials is approved under the current PHMC program involves the application of requirements similar to those imposed by DOT and the Nuclear Regulatory Commission (NRC) for the transportation of these materials in the public domain. Packaging design is a primary element in identifying the applicable requirements and the extent to which the shipments of HLW to the CSB must be controlled. Packaging systems that afford the greatest degree of protection for the contents require the lowest degree of operational control.

In order that the applicable requirements and approvals may be fully identified, the packaging design must be fully defined. The maximum intended payload must also be defined. Other parameters that should be established before the necessary approvals can be obtained include the shipment route and frequency.

\subsection{SUMMARY OF DATA/NFORMATION REQUIREMENTS}

The primary information required in order to proceed with authorization of the packaging system and the shipment campaign is as follows:

- Detailed design of the packaging system

- Description of the transportation system

- Detailed description of the bounding payload, including radioisotopic content, chemical constituents, physical properties, thermal properties, and mechanical properties

- Transport mode (highway or rail) and route

- Number and frequency of shipments. 


\subsection{DISCUSSION OF ALTERNATIVES}

The basic alternatives for approval of the transportation aspects of the HLW Interim Storage Project are limited. One approach is to fully comply with DOT and NRC regulations that govern the transportation of Type B quantities of radioactive material. A second alternative is to design and operate a packaging and transportation system under the PHMC onsite Transportation Safety Program as defined in WHC-CM-2-14, Hazardous Material Packaging and Shipping.

The first alternative, full regulatory compliance for offsite shipping, requires the use of a certified packaging system. Unless a currently certified system is identified and is usable for this campaign, the selection of this alternative typically requires an effort of two to five years to obtain certification of the packaging design, along with significant cost to execute the process. Another difficulty that would be encountered if this alternative were selected is the necessity to fully characterize the material being shipped, a process that may not be completed until the production of the payload is well underway. Advantages of this alternative include the possession of a well-established pedigree from an independent regulatory agency that is obtained through a defined process. This approach is clearly conservative from a safety perspective.

The second alternative, approval under the onsite transportation safety program, is more flexible and deals with safety aspects of the operation that do not contribute to the evaluations performed in support of the first alternative. The flexibility of this alternative lies in the safety criteria, which are based on potential dose consequences corresponding to accident frequencies. The advantages of this alternative include the use of less expensive packaging systems that are less cumbersome to handle. The onsite packaging and transportation procedures can be developed to apply as low as reasonably achievable (ALARA) principles in a manner not permitted by the first alternative. A disadvantage of this approach is that the packaging system would not be approved for shipment offsite to a final storage location.

\subsection{RECOMMENDED APPROVAL STRATEGY}

The recommended approval strategy for the packaging and transportation system is to conduct the design and safety evaluations within the onsite transportation safety program as described in WHC-CM-2-14, taking full advantage of the flexibility and cost efficiency provided by this approach. The packaging design and safety evaluations should be conducted in parallel.

\subsection{PRELIMINARY COST ESTIMATE}

(See Appendix A) 


\subsection{RADIATION PROTECTION STANDARDS/MONITORING}

\subsection{INTRODUCTION}

DOE Order 5400.1, General Environmental Protection Program, and DOE Order 5400.5, Radiation Protection of the Public and the Environment, require that monitoring be performed to determine the impact on the environment from activities that involve potential emission of radionuclides.

\subsection{SUMMARY OF DATA OF INFORMATION REQUIREMENTS}

Both DOE orders require that baseline data be obtained prior to the start of a project, and that periodic monitoring be performed to determine if the environment is being affected. The baseline data required include:

- Background radiation levels at the project site and in surrounding areas, including on-site and off-site.

- Radionuclides present in flora, fauna, soil, wildlife, water, vadoze and ground water, agriculture products and animals, and, in some circumstances, members of the public.

\subsection{DISCUSSION OF ALTERNATIVES}

The three alternatives available for this project are: 1) gather the required information specifically for this project; 2) use information gathered by Spent Nuclear Fuels and routine monitoring of the Hanford Site; and 3) use routine monitoring data for the Hanford Site supplemented by project-specific data related to the location of the CSB and storage of the canisters.

Alternative 1, gathering the data specifically for this project, would duplicate a considerable amount of monitoring work that is routinely performed regarding the Hanford Site and facilities. Also, for much of the preferred 2-year baseline period, the Spent Nuclear Fuels project would be actively storing fuel in the CSB. This situation could bias the Hanford Site baseline data. Alternative 1 is judged to be the most expensive alternative, and has the longest schedule.

Alternative 2) makes use of existing data for the baseline and limits this project to ongoing monitoring. The ongoing monitoring can be accomplished by use of site programs and the specific monitoring established for storage by the Spent Nuclear Fuel project. It is not expected that storage of HLW canisters will require monitoring beyond that done by the 
routine site programs. However, because TWRS will become the facility manager, TWRS will be obligated to perform the periodic monitoring associated with storage of the fuel canisters.

Alternative 3) makes use of existing data, from both the Site and Spent Nuclear Fuels, supplemented by data specific to storage of HLW canisters. Because very little data can be separated from the Spent Nuclear Fuels use of the Canister Storage Building this option is not viable.

\subsection{RECOMMENDED STRATEGY}

Use Alternative 2. Baseline data are required for this project; however, no specific action is needed because the same data are required for storage of the spent nuclear fuel or as part of other routine Hanford Site monitoring. The HLW canisters are not expected to have radioactive emissions; however, monitoring is provided by the radiation sampling system installed on the building ventilation system. This system is required for the spent nuclear fuel canisters as there is a potential for radioactive gas emissions.

Although not required by the DOE Orders, it is recommended that the below deck passive ventilation system have the capability to place an isokenetic or shrouded probe in the exhaust stack. This can be accomplished by adding two to four 2-inch-diameter openings to the stack. The openings would connect to 150-pound rated, raised face flanges with blank covers. These openings could also be used to confirm expect air flow. Expected cost is $\$ 5,000$ or less, installed.

\subsection{PRELIMINARY COST ESTIMATE}

(See Appendix A) 
HNF-SD-ENV-EE-002 Rev. 0

\subsection{REFERENCES}

10 CFR 1021, 1992, "Compliance with the National Environmental Policy Act," Code of Federal Regulations, as amended.

40 CFR 260, 1980, "Hazardous Waste Management System: General," Code of Federal Regulations, as amended.

40 CFR 261, 1980, "Identification and Listing of Hazardous Waste," Code of Federal Regulations, as amended.

40 CFR 268, 1986, "Land Disposal Restrictions," Code of Federal Regulations, as amended.

62 FR 8692, 1996, "U.S. Department of Energy Record of Decision for the Tank Waste Remediation System, Hanford Site, Richland, Washington," Federal Register, Vol. 62, pp. 8692-8704, (February 26).

DOE, 1988, General Environmental Protection Program, DOE Order 5400.1, U.S. Department of Energy, Washington, D.C.

DOE, 1990, Radiation Protection of the Public and the Environment, DOE Order 5400.5, U.S. Department of Energy, Washington, D.C.

DOE, 1991, General Information Portion, DOE/RL-91-28, U.S. Department of Energy, Richland Operations Office, Richland, Washington.

DOE, 1996a, Final Environmental Impact Statement: Management of Spent Nuclear Fuel from the K-Basins at the Hanford Site, Richland, Washington, DOE/EIS-0245-F, U.S. Department of Energy, Richland Operations Office, Richland, Washington.

DOE, 1996b, Final Environmental Impact Statement for the Tank Waste Remediation System, DOE/EIS-0189F, U.S. Department of Energy, Richland Operations Office, Washington.

DOE, 1996c, Spent Nuclear Fuels/Final Environmental Impact Statement, DOE/EIS-0245F, U.S. Department of Energy, Richland Operations Office, Richland, Washington.

National Environmental Policy Act of 1969, 42 USC 4321 et seq.

Resource Conservation and Recovery Act of 1976, 42 USC 6901 et seq.

State Environmental Policy Act of 1971, RCW 43.21C, Revised Code of Washington, et seq. 
WAC 173-303, 1996, "Dangerous Waste Regulations," Washington Administrative Code, as amended.

WAC 197-11, 1986, "Washington State Environmental Policy Act Rules, Department of Ecology," Washington Administrative Code, as amended.

WHC-CM-2-14, Hazardous Material Packaging and Shipping, Westinghouse Hanford Company, Richland, Washington. 
HNF-SD-ENV-EE-002 Rev. 0

APPENDIX A

HIGH-LEVEL WASTE INTERIM STORAGE

PERMITTING PLAN COST AND SCHEDULE 
HNF-SD-ENV-EE-002 Rev. 0

This page intentionally left blank.

A-2 
HNF-SD-ENV-EE-002 Rev. 0

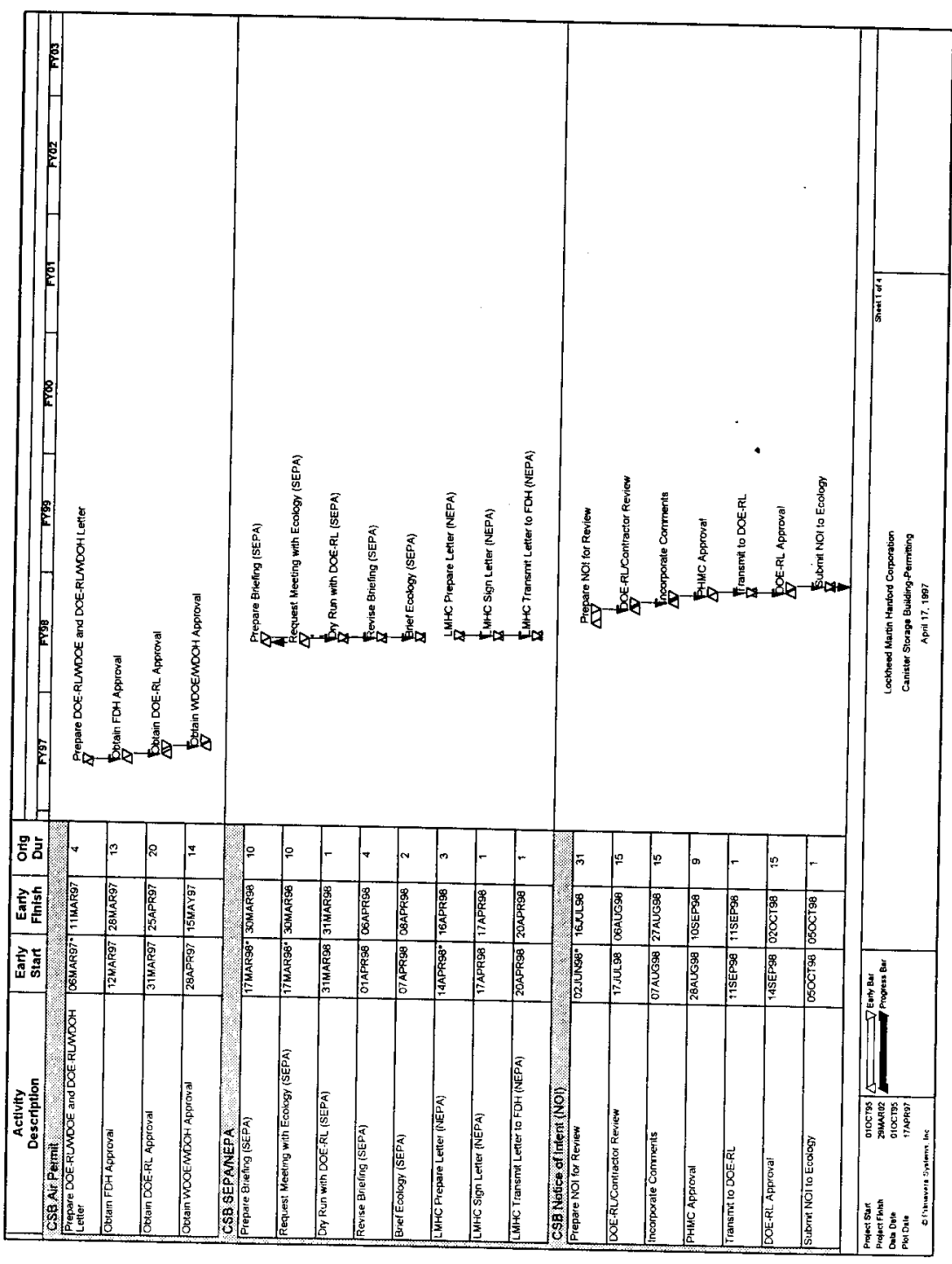


HNF-SD-ENV-EE-002 Rev. 0

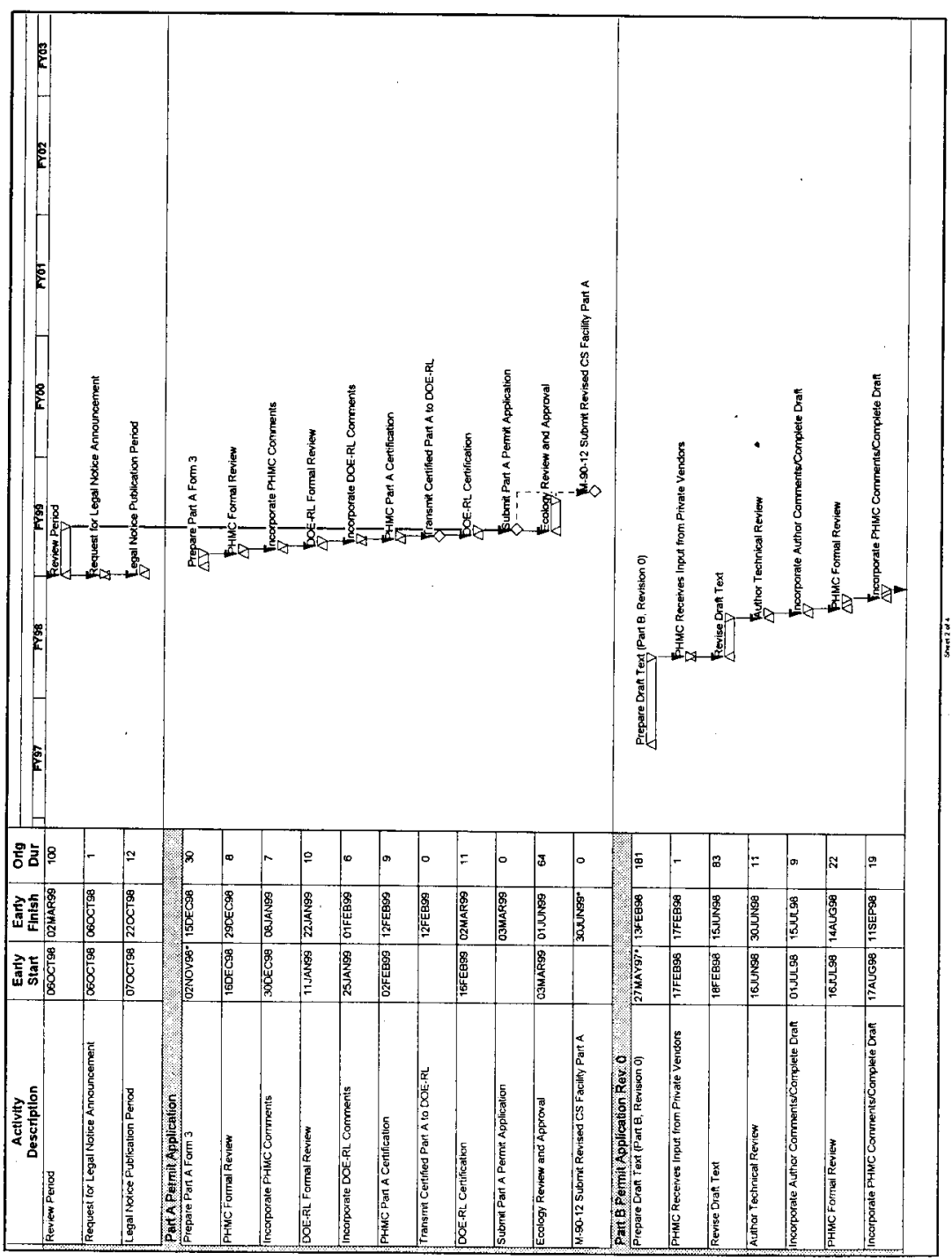


HNF-SD-ENV-EE-002 Rev. 0

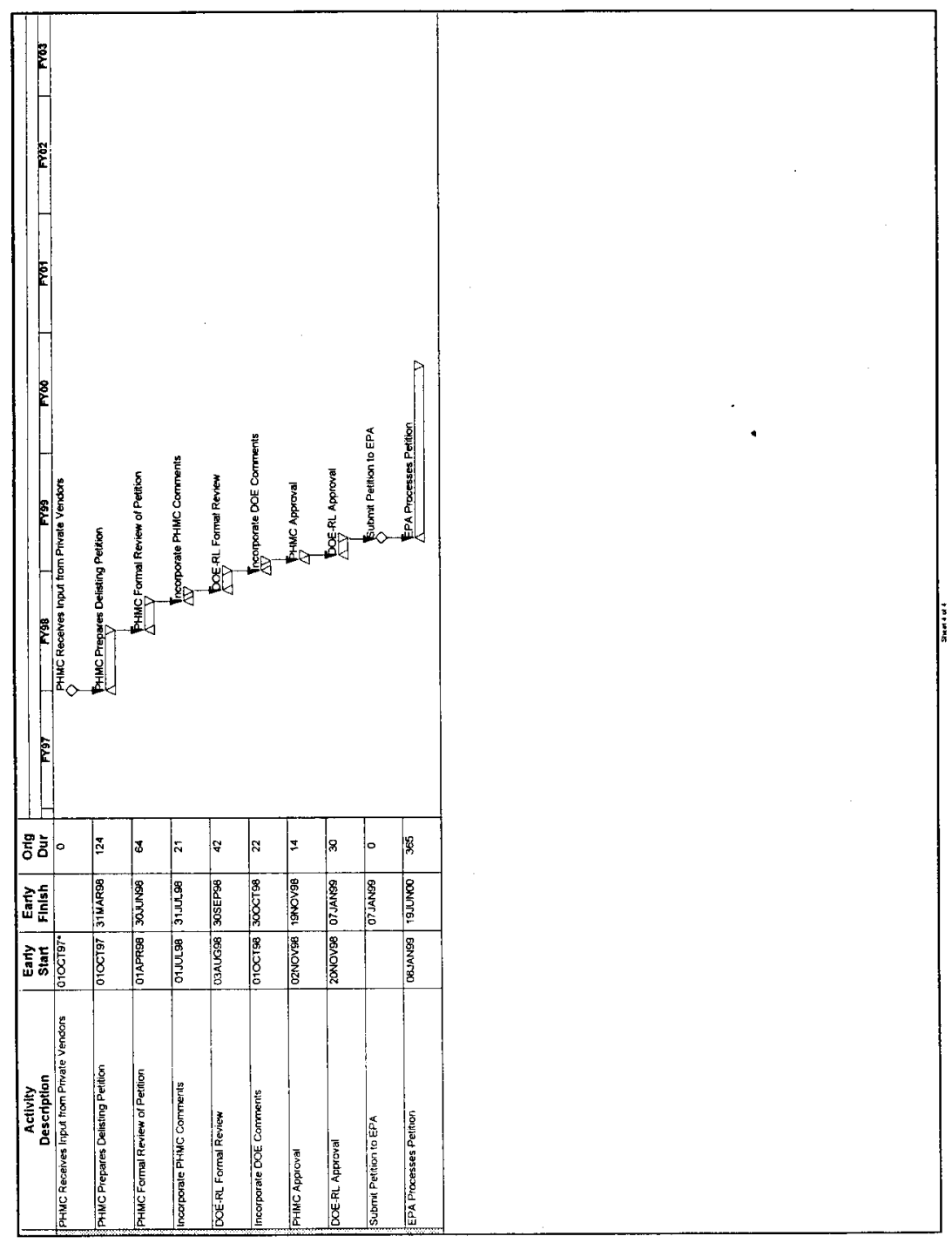




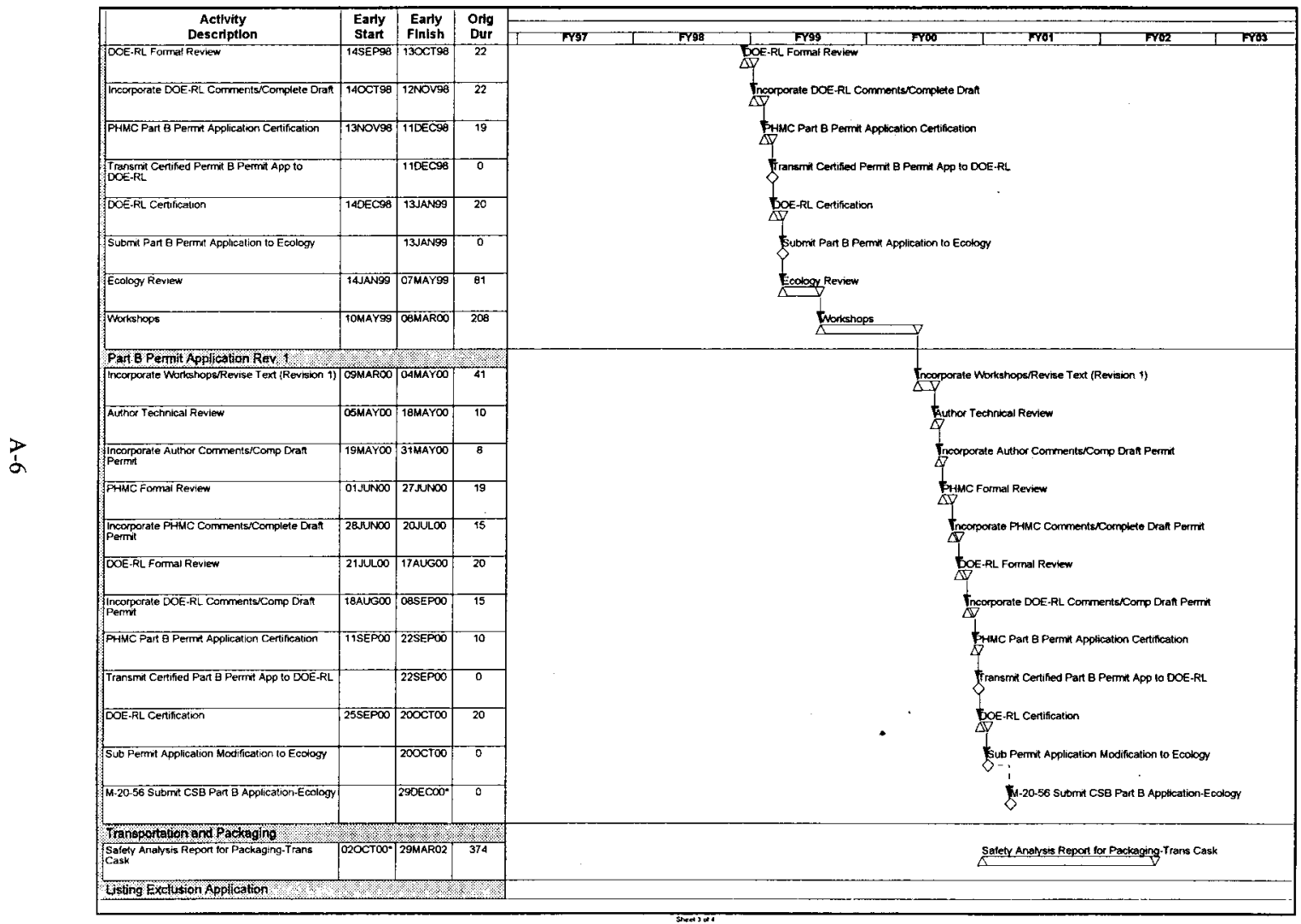


HNF-SD-ENV-EE-002 Rev. 0

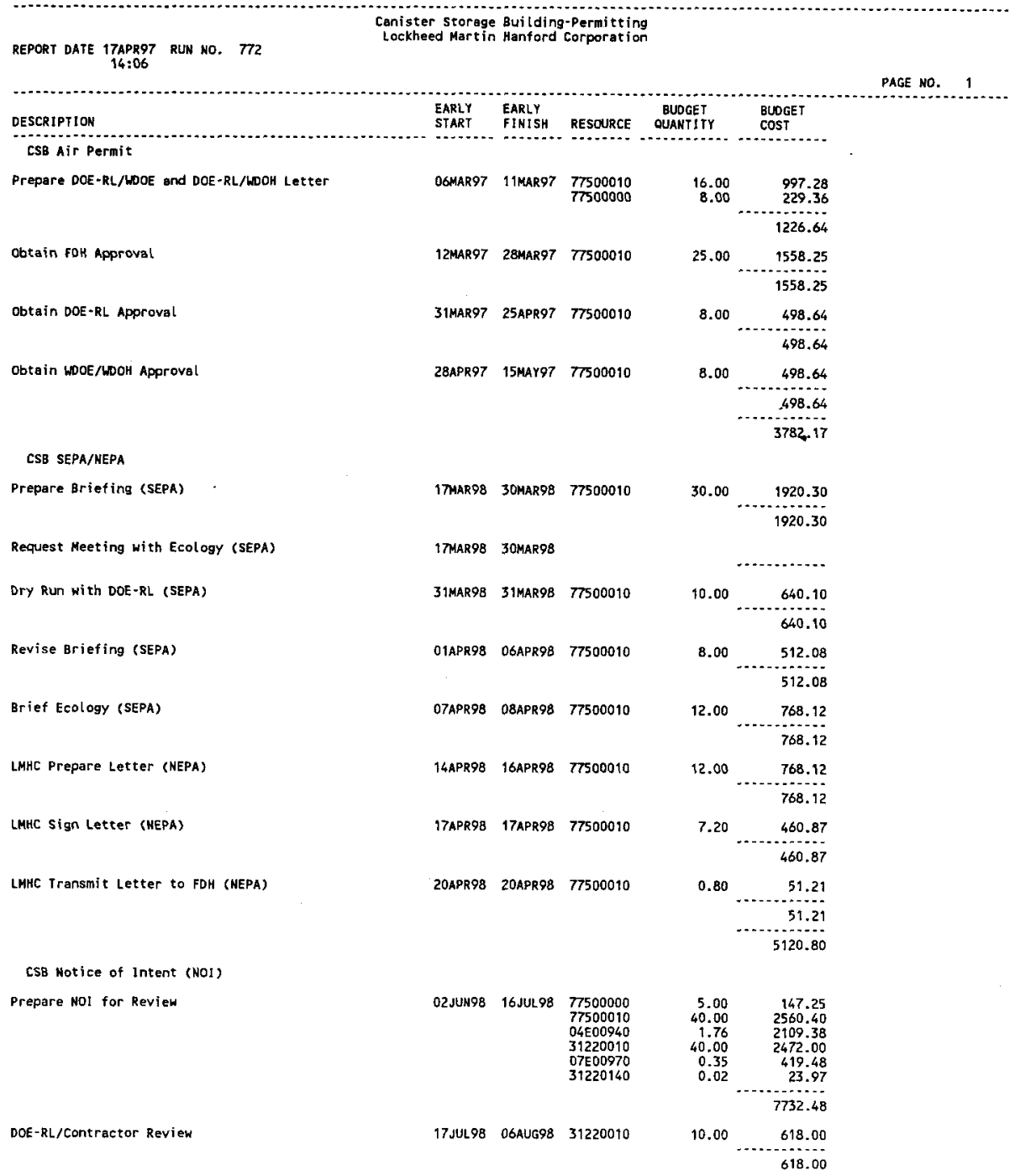


HNF-SD-ENV-EE-002 Rev. 0

\section{Canister storage Building-Permitting}

Lockheed Martin Hanford Corporation

REPORT DATE ITAPR97 RUN NO. 772 14:06

PAge No, 2

DESCR IPTION
CSB Notice of Inten
Incorporate Comments

EARLY EARLY

EARLY EARLY

START FINISH RESOURCE QUANTITY

RESOURCE

BUDGET

BUDGE T $\cos T$

Incorporate Comments

PHMC Approval

Transmit to DOE $\cdot R t$

DOE-RL Approval

Submit MOI to Ecology

Review Period

Request for Legal Notice Announcement

Legal Hotice Publication Period

Part A Permit Application

Prepare Part A Form 3

PHMC Formal Review

Incorporate PHMC Comments

DOE-RL Formal Review

Incorporate DOE-RL Comments

PHMC Part A Certification

Iransmit Certified Part A to DOE-RL

07aug98 z7auggo 77500010
$04 E 00940$
31220010
$07 E 00970$ 31220140

28AUG98 105EP98

77500010 31220010

11 SEP98 11SEP98
14 SEP98 020CT98

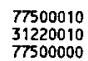

050CT98 050CT98

$\begin{array}{ll}060 C 198 & \text { O2MAR99 } \\ 060 C T 98 & 060 C 198 \\ 070 C 198 & 220 C T 98\end{array}$

- n.

18672.85

D2NOV98 150EC98

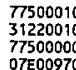

77500010
31220010
77500000
07200970

31220140
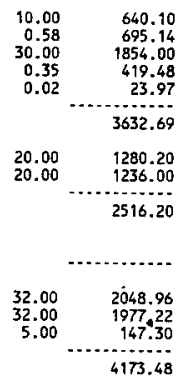

2516.20

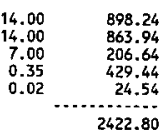

160 EC98 290EC98 3121001

$10.00 \quad \begin{array}{r}617.10 \\ 617.10\end{array}$

30DEC98 OBJAN99 31210010

$20.00 \quad 1234.20$

1234.20

11JAN99 22JAN99 31210010

$10.00 \quad 617.10$

617.10

25JAN99 O1FEB99 $31220010 \quad 10.00 \quad 617.10$

$\begin{array}{lll}07 E 00970 & 0.35 & 429.44\end{array}$

$\begin{array}{rrr}31220140 & 0.02 & 24.54\end{array}$

$312204 \mathrm{CO} \quad 0.01 \quad 12.27$

1083.35

O2FEB 99 12FEB99 31210010

$15.00 \quad 925.65$
$\quad 925.65$

12FEB99 
HNF-SD-ENV-EE-002 Rev. 0

Canister storage Building-Permitting

Lockheed Mart in Hanford Corporation

REPORT DATE 17APR97 RUN NO. 772

$14: 06$

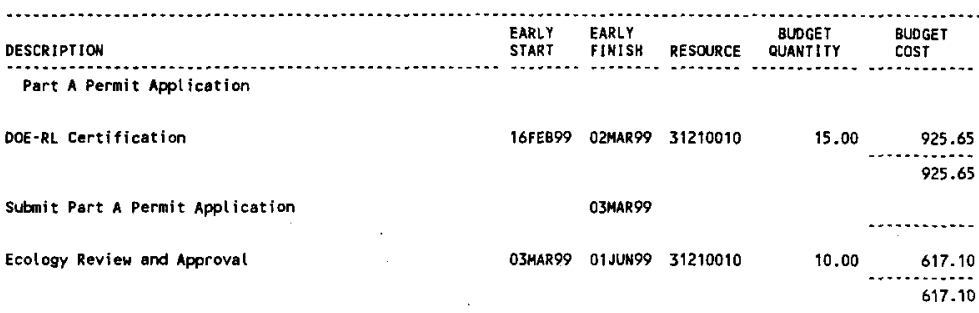

(M-90-12) Submit Revised cS Facility Part A

30 JUN99

Part B Permit Application Rev. 0

Prepare Draft Text (Part B, Revision O)

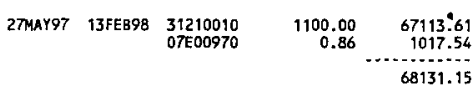

PHMC Receives Input from Private Vendors

17FEB98 17FEB98

Revise Draft Text

18FEB98 15 JUVG8

31210010 $07 E 00970$

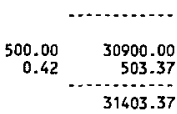

Author Technical Review

16.JUN98 30JUN98 31210010

$17.00 \quad 1050.60$
1050.60

Incorporate Author Comments/Complete Draft

01JUL98 15JUL98 31210010

$40.00 \quad 2472.00$

2472.00

PHMC Formal Review

16JUL.98 14AUG98

47400060 31210140 31210400

$10.00 \quad 618.00$

$19.00 \quad 745.75$

$\begin{array}{lr}0.42 & 503.37 \\ 0.03 & 35.96\end{array}$

1903.08

Incorporate PHMC Comments/Complete Draft

DOE-RL, Formal Review

$30.00 \quad 1854.00$

1854.00

14SEP98 $130 \mathrm{CT98} \quad 31210010 \quad 10.00 \quad 617.63$

$47400060 \quad 19.00 \quad 752.98$

$0.41 \quad 496.16$

$\begin{array}{lr}0.41 & 496.16 \\ 0.03 & 36.30\end{array}$

1903.07

Incorporate DOE-RL Comments/Complete Draft

$140 \mathrm{CT} 98 \quad 12 \mathrm{NOV} 9 \mathrm{~B}$

31210010 $07 E 00970$

13\%OV98 $110 \mathrm{ECOB} \quad 31210010$

$0.00 \quad 1851.30$

$0.41 \quad 503.06$

2354.36

PHMC Part B Permit Application Certification

Transmit Certified Permit B Permit APP to DOE-RL

110 EC98

DOE-RL Certification

PAGE NO. 3

...


HNF-SD-ENV-EE-002 Rev. 0

Canister storage Building Permitting

Lockheed Mart in Hanford Corporat ion

REPORT DATE 17APR97 RUN NO. TT2 14:06

DESCRIPIION
Part B Permit Application Rev. 0 $\quad \begin{aligned} & \text { EARLY } \\ & \text { START }\end{aligned}$

2103.76

Submit Part B Permit Application to Ecology

Ecology Review

Workshops

Part B Permit Application Rev. 1

Incorporate Horkshops/Revise Text (Revision 1)

Author Technical Review

Incorporate Author Comments/Comp Draft Permit

PHMC Formal Review

Incorporate PHMC Comments/Complete Draft Permit

DOE-RL Formal Review

Incorporate DOE-RL, Comments/Comp Draft Permit

PHMC Part B Permit Application Certification

Transmit Certified Part B Permit App to DOE-RL

DOE-RL Certification

Sub Permit Application Modification to Ecology

(M-20-56) Submit CSB Part B Application-Ecology
13.JAN99

14.JAN99 O7MAY99

IOMAY99 O8MAROO 31210010

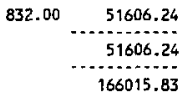

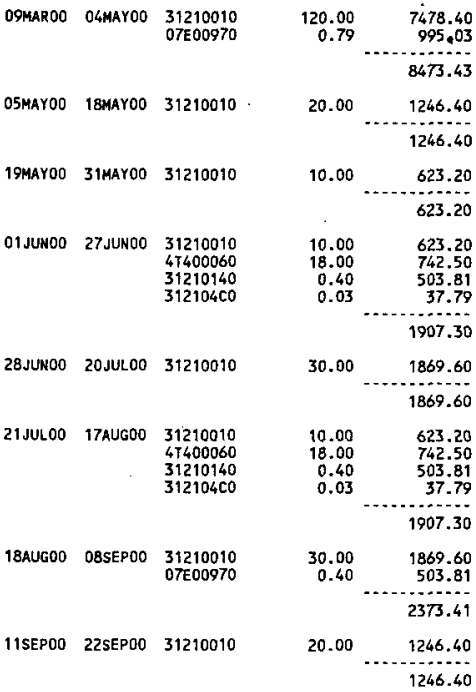

22SEPOO

25SEPOO 200CTOD 31270010 $4 T 400060$

$\begin{array}{rr}90.00 & \begin{array}{r}63 \\ 36.00\end{array} \quad+514.70 \\ -2138.50\end{array}$

200CT00

290EC00
PAGE HO. 4

....


HNF-SD-ENV-EE-002 Rev. 0

Canister Storage Building-Permitting

Lockheed Martin Hanford Corporation REPORT DATE $\underset{17 A P R 97}{14: 06}$ RUN NO. 772

PAGE NO. 5

\begin{tabular}{|c|c|c|c|c|c|}
\hline Transportation and Packaging & & & & & \\
\hline Safety Analysis Report for Packaging-Trans Cask & $020 \mathrm{CT00}$ & 29MAR02 & O3E00930 & 191.83 & $\begin{array}{r}250014.46 \\
250014.46 \\
250014.46\end{array}$ \\
\hline
\end{tabular}

tisting Exclusion Application

PHMC Receives Input from Private Vendors

PHMC Prepares Delisting Petition

PHMC Formal Review of Petition

Incorporate PHWC Comments

DOE-RL Formal Revieh

Incorporate DOE Comments

PHMC Approval

DOE-RL Approval

Submit Petition to EPA

EPA Processes Petition
$010 \mathrm{cT} 97$

$010 C T 97$ 31MAR98 70310010

30JUN98 70310010

01JUL98 31JUL98 70310010

$010 \mathrm{CT98} 300 \mathrm{CT98} \quad 70310010$

02NOV98 19NOV9B 70310010

20NOV9S 07JAN99 70310010

07.JAN99

08Jan99 19JUn00 70310010

$$
\begin{array}{rr}
1820.00 & 116498.20 \\
& 116498.20 \\
480.00 & 30724.80 \\
& 30724.80 \\
240.00 & 15362.40 \\
& 15362.40 \\
& 5120.80 \\
80.00 & 5120.80 \\
& 10265.60 \\
160.00 & 10265.60 \\
& 1283.20 \\
& \\
& \\
& \\
& 1283.20 \\
& 1283.20 \\
20.00 & 1283.20
\end{array}
$$

$\begin{array}{rr}20.00 & 1283.20 \\ & 1283.20\end{array}$

$$
\begin{array}{r}
500.00 \quad 32223.01 \\
32223.01 \\
212761.21 \\
==========1 \\
686595.81
\end{array}
$$


HNF-SD-ENV-EE-002 Rev. 0

This page left blank intentionally. 
HNF-SD-ENV-EE-002 Rev, 0

\section{APPENDIX B}

ENVIRONMENTAL REQUIREMENTS CHECKLIST FOR THE HIGH-LEVEL WASTE STORAGE PROJECT CANISTER STORAGE BUILDING 
HNF-SD-ENV-EE-002 Rev. 0

This page intentionally left blank.

B-2 
Date: $\quad 11-04-96$

ENVIRONMENTAL REQUIREMENTS CHECKLIST FOR THE HIGH-LEVEL WASTE STORAGE PROJECT CANISTER STORAGE BUILDING

\begin{tabular}{llll}
\multicolumn{1}{c}{ K. C. Burgard } & H5-03 & & \\
cc: & & & H5-24 \\
B. G. Erlandson & R2-36 & E. E. Mayer & H5-27 \\
F. M. P. Delozier & S7-85 & R. B. Calmus & S7-01 \\
H. L. Boston & H5-24 & K. S. Tollefson & S2-48 \\
C. C. Haas & S7-51 & D. G. Baide & S5-03 \\
P. H. Miller & R1-51 & R. K. P'Pool & \\
MLD File/LB & & &
\end{tabular}

Please find attached the Environmental Requirements Checklist for the High-Level Waste Interim Storage Project. This checklist documents TWRS Environmental Compliance's evaluation of the required environmental permits, approvals, and/or other documentation necessary for this project, and lists the contact person for each requirement.

The High-Level Waste (HLW) Interim Storage Project plans on using the existing Spent Nuclear Fuels (SNF) Canister Storage building for interim storage of solidified (HLW) produced during the Phase 1 privatization effort. Solidified HLW includes canisters containing vitrified (glass) HLW and containers containing cesium separated from waste by ion exchange into resin during low-level waste pretreatment.

M. L. Deffenbaugh

Environmental Engineer

TWRS Environmental Compliance

MLD

Attachment 
HNF-SD-ENV-EE-002 Rev. 0

\section{SCOPE OF WORK FOR}

\section{HIGH-LEVEL WASTE INTERIM STORAGE PROJECT}

\section{EXPLANATION OF ENVIRONMENTAL REQUIREMENTS CHECKLIST AND NARRATIVE}

The following table identifies environmental permits, approvals, and/or requirements applicable to the project. Any "Yes" or "To Be Determined" answer in the applicability column will be further described in the narrative that follows the table. Some "No" answers may require special explanation and will have narrative associated with them. If this is the case, the words "See Narrative" will be stated in the applicability column. A contact is identified at the end of each evaluation to answer questions and/or provide additional information regarding the specific regulation in question.

The path forward for solidified high-level waste (HLW) interim storage entails use of the Spent Nuclear Fuels (SNF) Canister Storage Building (CSB) for interim storage of solidified HLW produced during the Phase I privatization effort (Calmus 1996). The CSB is designed as a "zero discharge" facility. Engineering assessments have indicated that excess CSB vauits (two southern most vaults 2 and 3 ) could, with some modification, be used for immobilized HLW interim storage (Jacobs 1996). A permitting checklist was developed for the SNF CSB construction and operation. However, this checklist was not developed with the intent to store Phase I HLW products. Therefore, this Environmental checklist will address the specific storage of Phase I HLW products in the CSB. This permitting checklist will provide the basis to develop a permitting plan concurrent with HLW Interim Storage Project CSB conceptual design.

This environmental checklist does not encompasses the storing of shipping port fuel, however, this is a living document that will evolve with the needs of the project. 


\section{ABBREVIATIONS and ACRONYMS}

\begin{tabular}{|c|c|}
\hline $\mathrm{ADM}$ & Action Description Memorandum \\
\hline AL,ARA & As Low As Reasonably Achievable \\
\hline AOP & Air Operating Permit \\
\hline ARARs & Applicable or Relevant and Appropriate Requirements \\
\hline BACT & Best Available Control Tectnology \\
\hline BARCT & Best Available Radionuclide Control Technology \\
\hline BCCAA & Beoton County Clean Air Authority \\
\hline BFDHD & Henton-Frarklin District Health Department \\
\hline CAA & Clean Air Act \\
\hline CDR & Conceptual Design Report \\
\hline CERCLA & Comprehensive Environmental Response, Compensation, and Liability Act \\
\hline CFC & Chlorofluorocarbons \\
\hline CFR & Code of Pederal Regulations \\
\hline CRR & Cultural Resource Review \\
\hline $\mathrm{CX}$ & Categorical Exclusion \\
\hline DOE-HQ & U.S. Department of Energy-Headquarters \\
\hline DOH & State of Washington Department of Health \\
\hline DST & double-shell tank \\
\hline EA & Environmental Assessment \\
\hline Ecology & State of Washington Department of Ecology \\
\hline EIS & Environmental lmpact Statement \\
\hline EIS/ODIS & Effluent Information System/Onsite Discharge Information System \\
\hline EPA & U.S. Evvironmental Protection Ageacy \\
\hline $\mathrm{HR}$ & Federal Register \\
\hline FONSI & Finding of No Significant Impact \\
\hline gpd & gallons per day \\
\hline HCRL & Hanford Cultural Resource Laboratory \\
\hline HLAN & Hanford Local Area Network \\
\hline HPA & Hydraulic Projects Approval \\
\hline IB & Information Bulletin \\
\hline IEU & insignificant emjssion onits \\
\hline LDUA & light duty utility arm \\
\hline MEI & Maximum Exposed Individual \\
\hline mrem & millirem \\
\hline MTF & Memorandum-To-File \\
\hline MWC & Municipal Waste Combustor \\
\hline NEPA & National Environmental Policy Act \\
\hline NESHAPs & National Emission Standards for Hazardous Air Pollutants \\
\hline NOC & Notice of Construction \\
\hline NOI & Notice of lntent \\
\hline NPDES & National Pollutant Discharge Elimination System \\
\hline NSR & New Source Review \\
\hline POC & Point of Contact \\
\hline PL & Public Law \\
\hline PNNL & Pacific Northwest National Laboratory \\
\hline PSD & Prevention of Significant Deterioration \\
\hline RCRA & Resource Conservation and Recovery Act \\
\hline RL & U.S. Department of Energy, Richland Operations Office \\
\hline SEPA & State Environmentat Policy Act \\
\hline SST & single-shell tank \\
\hline SWDP & State Waste Discharge Permit \\
\hline TAPs & Toxic Air Pollutants \\
\hline T-BACT & Best Available Control Technology for Toxics \\
\hline TEDE & Total Effective Dose Equivalent \\
\hline T-RACT & Reasonably Available Control Technology for Toxics \\
\hline Tri-Party Agreement & Hanford Federal Facility Agreernent and Consent Order \\
\hline TSD & Treatment, Storage, and/or Disposal \\
\hline UIC & Underground Injection Control \\
\hline USACE & U.S. Army Corps of Engineers \\
\hline UST & Underground Storage Tanks \\
\hline WAC & Washington Administrative Code \\
\hline WHC & Westinghouse Hanford Company \\
\hline
\end{tabular}




\section{Summary Checklist of Potential Permits/Approvals/Requirements}

(4 sheets)

\begin{tabular}{|c|c|c|c|c|c|}
\hline $\begin{array}{c}\text { Environment- } \\
\text { Media }\end{array}$ & $\begin{array}{l}\text { Permit, Approval, } \\
\text { Or Requirement }\end{array}$ & Regulation(s) & $\begin{array}{l}\text { Regulatory } \\
\text { Agency }\end{array}$ & Restriction & $\begin{array}{c}\text { App. } \\
(\mathrm{Y} \text { or } \mathrm{N})\end{array}$ \\
\hline NEPA & NEPA Documentation & 10 CFR 1021 & DOE & $\begin{array}{l}\text { Title II Design } \\
\text { (Projects); } \\
\text { Procurement }\end{array}$ & $\gamma$ \\
\hline SEPA & SEPA & WAC 197-11 & State Agency & License; Permit & Nilntitite \\
\hline CERCLA & ARARs & 40 CFR 300 to 400 & EPA & Construction & X. \\
\hline \multirow[t]{4}{*}{$\begin{array}{l}\text { Nonrad. Air } \\
\text { Emissions }\end{array}$} & $\begin{array}{l}\text { New Source } \\
\text { Review/NOC; Source } \\
\text { Registration } \downarrow\end{array}$ & $\begin{array}{l}\text { WAC } 173-400-040 \\
\text { WAC } 173-400-110\end{array}$ & Ecology; & Construction & $\mathbf{N}$ \\
\hline & PSD & WAC $173-400-141$ & Ecology; & Construction & X \\
\hline & TAPS & $\begin{array}{l}\text { WAC 173-460-030; } \\
-040\end{array}$ & Ecology & Construction & X \\
\hline & $\begin{array}{l}\text { Dangerous and/or } \\
\text { Hazardous waste } \\
\text { air emissions }\end{array}$ & $\begin{array}{l}\text { WAC 173-303 } \\
-120(4)(e),-400(3), \\
-690, \text { and }-691, \\
40 \text { CFR } 264 / 265 \\
\text { Subpart CC }\end{array}$ & $\begin{array}{l}\text { Ecology } \\
\text { and } \\
\text { EPA }\end{array}$ & Operations & t) \\
\hline \multirow[t]{2}{*}{$\begin{array}{l}\text { Radioactive } \\
\text { Air Emissions }\end{array}$} & NESHAPS & $\begin{array}{l}40 \text { CFR 61, Subpart } \\
\text { H }\end{array}$ & EPA & Construction & X \\
\hline & $\begin{array}{l}\text { Radiation Protection - } \\
\text { Air Emissions }\end{array}$ & WAC 246-247-060 & $\mathrm{DOH}$ & $\begin{array}{l}\text { Construction; } \\
\text { Operation }\end{array}$ & X \\
\hline $\begin{array}{l}\text { All Air } \\
\text { Emissions }\end{array}$ & Air Operating Permit & WAC 173-401 & $\begin{array}{l}\text { Ecology; } \\
\text { DOH; EPA }\end{array}$ & Operation & Viritive \\
\hline Asbestos & $\mathrm{NOI}$ & $\begin{array}{l}\text { BCCAA Reg. 1, } \\
\text { Article 8; } \\
40 \text { CFR 61, Subpart } \\
M\end{array}$ & $\mathrm{BCCAA}$ & $\begin{array}{l}\text { Before Working } \\
\text { with Asbestos }\end{array}$ & (1) \\
\hline $\begin{array}{l}\text { Outdoor or } \\
\text { Unconfined } \\
\text { Burning }\end{array}$ & Burn Permit & $\begin{array}{l}\text { WAC 173-425; } \\
\text { BCCAA Reg. } 1 \text {, } \\
\text { Article } 5\end{array}$ & $\begin{array}{l}\text { Hanford Fire } \\
\text { DepartmentB } \\
\text { CCAA }\end{array}$ & Open Burning & T. \\
\hline
\end{tabular}




\section{Summary Checklist of Potential Permits/Approvals/Requirements}

(4 sheets)

\begin{tabular}{|c|c|c|c|c|c|}
\hline $\begin{array}{l}\text { Environment- } \\
\text { Media }\end{array}$ & $\begin{array}{l}\text { Permit, Approval, } \\
\text { Or Requirement }\end{array}$ & Regulation(s) & $\begin{array}{l}\text { Regulatory } \\
\text { Agency }\end{array}$ & Restriction & $\begin{array}{c}\text { App. } \\
(\mathrm{Y} \text { or } \mathrm{N})\end{array}$ \\
\hline $\begin{array}{l}\text { Ozone Depleting } \\
\text { Substances/ } \\
\text { CFCs }\end{array}$ & $\begin{array}{l}\text { Release Prevention; } \\
\text { Recovery/Recycle; } \\
\text { Certification Labeling }\end{array}$ & 40 CFR 82 & Ecology & $\begin{array}{l}\text { Reporting; } \\
\text { Training; } \\
\text { Operation }\end{array}$ & X: \\
\hline \multirow{3}{*}{$\begin{array}{l}\text { Soil Column } \\
\text { Waste Water } \\
\text { Disposal }\end{array}$} & SWDP & WAC $173-216$ & Ecology & Operation & 16 \\
\hline & $\begin{array}{l}\text { Approval of Engr. } \\
\text { Report, Plans \& } \\
\text { Specs., and O\&M } \\
\text { Manual }\end{array}$ & WAC $173-240$ & Ecology & Construction & \% \\
\hline & $\begin{array}{l}\text { UIC Permit/ } \\
\text { Registration }\end{array}$ & WAC 173-218 & Ecology & Operation & XY \\
\hline \multirow[t]{5}{*}{$\begin{array}{l}\text { Domestic Waste } \\
\text { Water Disposal }\end{array}$} & $\begin{array}{l}\text { Septic Systems } \\
<14,500 \text { gpd } \\
\text { Capacity Design } \\
\text { Approval }\end{array}$ & WAC 246-272 & $\mathrm{DOH}$ & Construction & 11. \\
\hline & $\begin{array}{l}\text { Septic Systems } \\
>14,500 \text { gpd } \\
\text { Capacity Design } \\
\text { Approval }\end{array}$ & $\begin{array}{l}\text { WAC 173-216; } \\
\text { WAC } 173-240\end{array}$ & Ecology & Construction & W \\
\hline & Pretreatment Permit & $\begin{array}{l}40 \text { CFR } 403 ; \\
\text { City Ordinance }\end{array}$ & $\begin{array}{l}\text { City of } \\
\text { Richland }\end{array}$ & $\begin{array}{l}\text { Discharge to City } \\
\text { Sewage Facility }\end{array}$ & Y. \\
\hline & Operator Certification & WAC $173-230$ & Ecology & Operation & Y) \\
\hline & Discharge Standards & WAC $173-221$ & Ecology & Discharge & I \\
\hline \multirow{4}{*}{$\begin{array}{l}\text { Surface Waste } \\
\text { Water Disposal }\end{array}$} & NPDES Permit & 40 CFR 122 & EPA & Operation & 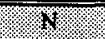 \\
\hline & $\begin{array}{l}\text { Storm Water } \\
\text { Discharge Under } \\
\text { General Permit }\end{array}$ & 57 FR No. 175 & EPA & River Construction & YY. \\
\hline & $\begin{array}{l}\text { U.S. Dept. of Army } \\
\text { Permit }\end{array}$ & 33 CFR 325 & USACE & River Construction & W \\
\hline & Section 10 Permit & $\begin{array}{l}33 \text { CFR } 320 ; \\
33 \text { CFR } 322\end{array}$ & USACE & River Construction & W. \\
\hline
\end{tabular}




\section{Summary Checklist of Potential Permits/Approvals/Requirements}

(4 sheets)

\begin{tabular}{|c|c|c|c|c|c|}
\hline $\begin{array}{l}\text { Environment- } \\
\text { Media }\end{array}$ & $\begin{array}{l}\text { Permit, Approval, } \\
\text { Or Requirement }\end{array}$ & Regulation(s) & $\begin{array}{c}\text { Regulatory } \\
\text { Agency }\end{array}$ & Restriction & $\begin{array}{c}\text { App. } \\
\text { (Y or } \mathrm{N})\end{array}$ \\
\hline & Nationwide Permits & 33 CFR 330 & USACE & River Construction & 1) \\
\hline & $\begin{array}{l}\text { Hydraulic Projects } \\
\text { Permit }\end{array}$ & WAC $220-110$ & $\begin{array}{l}\text { WA State } \\
\text { Dept. of } \\
\text { Fisheries }\end{array}$ & River Construction & x \\
\hline & $\begin{array}{l}\text { Shoreline } \\
\text { Development Permit }\end{array}$ & WAC $173-14$ to -20 & $\begin{array}{l}\text { Benton } \\
\text { County }\end{array}$ & $\begin{array}{l}\text { River/Island } \\
\text { Construction }\end{array}$ & अ \\
\hline & Aquatic Lands Lease & WAC 332-30 & DNR & Construction & 1 \\
\hline & $\begin{array}{l}\text { Hanford Reach Study } \\
\text { Act Notification }\end{array}$ & PL 100-605 & $\begin{array}{l}\text { U.S. Park } \\
\text { Service }\end{array}$ & $\begin{array}{l}\text { Construction } \\
\text { within } 1 / 4 \mathrm{mi} \text {. of } \\
\text { River }\end{array}$ & X. \\
\hline & $\begin{array}{l}\text { Water Quality } \\
\text { Modification Permit }\end{array}$ & WAC $173-201$ & Ecology & River Construction & H \\
\hline & $\begin{array}{l}\text { Certification of } \\
\text { NPDES Permit }\end{array}$ & 40 CFR 121 & Ecology & Operation & T. \\
\hline & Categorical Standards & 40 CFR 405 to 471 & EPA & Operation & W. \\
\hline \multirow[t]{3}{*}{$\begin{array}{l}\text { Drinking Water } \\
\text { Supply }\end{array}$} & $\begin{array}{l}\text { Approval of Engr. } \\
\text { Report, Plans \& } \\
\text { Specs. }\end{array}$ & WAC 246-290 & $\mathrm{DOH}$ & Construction & XI \\
\hline & System ID. Number & WAC 246-290 & $\overline{\mathrm{DOH}}$ & Operation & \% \\
\hline & Operator Certification & WAC 246-292 & $\mathrm{DOH}$ & Operation & X \\
\hline Solid Waste & $\begin{array}{l}\text { Solid Waste Handling } \\
\text { Facility Permit }\end{array}$ & WAC $173-304$ & BFDHD & Construction & 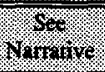 \\
\hline \multirow[t]{2}{*}{$\begin{array}{l}\text { Dangerous } \\
\text { Waste }\end{array}$} & $\begin{array}{l}\text { Dangerous Waste } \\
\text { Permit (RCRA } \\
\text { Part A and B) }\end{array}$ & $\begin{array}{l}\text { WAC } 173-303-800 \\
\text { thru-860; } \\
40 \text { CFR 264; } \\
40 \text { CFR 265; } \\
40 \text { CFR 270 }\end{array}$ & Ecology & \begin{tabular}{|l|} 
Construction of \\
New Facilities or \\
Expansion of \\
Existing Facilities
\end{tabular} & א. \\
\hline & $\begin{array}{l}\text { Construction or } \\
\text { expansion of surface } \\
\text { impoundments, waste } \\
\text { piles, or landfill } \\
\text { units }\end{array}$ & WAC $173-303-335$ & Ecology & $\begin{array}{l}\text { Construction } \\
\text { quality assurance } \\
\text { plans, program, } \\
\text { and certification }\end{array}$ & X. \\
\hline UST & Tank Permit & WAC $173-360$ & Ecology & Operation & W. \\
\hline
\end{tabular}


HNF-SD-ENV-EE-002 Rev. 0

Summary Checklist of Potential Permits/Approvals/Requirements

(4 sheets)

\begin{tabular}{|c|c|c|c|c|c|}
\hline $\begin{array}{l}\text { Environment- } \\
\text { Media }\end{array}$ & $\begin{array}{l}\text { Permit, Approval, } \\
\text { Or Requirement }\end{array}$ & Regulation(s) & $\begin{array}{l}\text { Regulatory } \\
\text { Agency }\end{array}$ & Restriction & $\begin{array}{c}\text { App. } \\
(\mathrm{Y} \text { or } N)\end{array}$ \\
\hline \multirow[t]{6}{*}{ All Media } & $\begin{array}{l}\text { Floodplain, Wetland } \\
\text { Assessment }\end{array}$ & 10 CFR 1022 & $\mathrm{DOE}$ & $\begin{array}{l}\text { Any Surface } \\
\text { Disturbance }\end{array}$ & $x$ \\
\hline & $\begin{array}{l}\text { Cultural Resource } \\
\text { Review }\end{array}$ & 36 CFR 800 & DOE & $\begin{array}{l}\text { Any Surface } \\
\text { Disturbance; } \\
\text { Modification of } \\
\text { Bldgs. Eligible for } \\
\text { Listing on } \\
\text { Historical Register }\end{array}$ & 1\%. \\
\hline & Excavation Permit & 36 CFR 800 & DOE & Any Excavation & $\frac{1}{2}$ \\
\hline & $\begin{array}{l}\text { Ecological } \\
\text { Compliance Review }\end{array}$ & $\begin{array}{l}10 \text { CFR } 1021 \\
50 \text { CFR } 402.6 \\
\text { DOE Order } 5484.1\end{array}$ & USFWS & $\begin{array}{l}\text { Construction; } \\
\text { Habitat } \\
\text { Modification }\end{array}$ & (1) \\
\hline & $\begin{array}{l}\text { Preoperational } \\
\text { Monitoring of } \\
\text { Facilities, Sites, and } \\
\text { Operations }\end{array}$ & DOE Order 5400.1 & $\mathrm{DOE}$ & Operation & (K) \\
\hline & $\begin{array}{l}\text { Radiation Protection } \\
\text { Standards }\end{array}$ & DOE Order 5400.5 & $\mathrm{DOE}$ & Construction & y \\
\hline
\end{tabular}


HNF-SD-ENV-EE-002 Rev. 0

NEPA

\section{NEPA Documentation - Title 10, CFR 1021}

A NEPA review is required for all proposed actions at the Hanford Site. Documentation of the completed NEPA review process could include an (EIS, an EA or a CX. The EIS is required for proposed major federal actions that could significantly affect the quality of the human environment. In cases where the need for an EIS is uncertain, an EA is prepared.

A CX is issued by RL if the proposed action clearly would have no significant impact on the quality of the human environment. However, most actions determined to be categorically excludable must be documented. A NEPA Documentation Request Checklist is available on Jetform on the Hanford Local Area Network that can be completed and forwarded to WHC NEPA Services to initiate the necessary review process.

NEPA Documentation must be completed before starting Title II Design.

Note: All cultural resource surveys and ecological survey/reviews must be completed before any NEPA documentation is submitted to RL.

EVALUATION: DOE/EIS-0189F Final Environmental Impact Statement for the Tank Waste Remediation System, Volume Two, Appendix B, B.3.9.3.1: Phase 1:

IMMOBLIZATION; par, 3; "The vitrified HLW would be placed directly into canisters. The HLW canisters $(0.61-\mathrm{m}$ [2-ft] diameter by $4.57-\mathrm{m}$ [15-ft] long) would be placed in transportation casks and transported to the canister storage building for interim storage. The canisters would be removed from the transportation casks and placed into storage tubes at one of the canister storage building vaults."

This satisfies the NEPA requirements for a portion of the Phase I HLW products, (vitrified glass). However, the containers containing cesium separated during low-level waste pretreatment were not mentioned in the EIS and would need to be revisited. There is also a possibility that "Shipping Port Fuel" will be stored in $5 \%$ of vault B. Both of the products will require reevaluation, most likely an EA will have to be written.

For additional information contact M. L. Deffenbaugh (373-5399), or B. G. Erlandson (372-2678). 
HNF-SD-ENV-EE-002 Rev. 0

SEPA

\section{SEPA Documentation - WAC 197-11}

SEPA is the State or local equivalent of NEPA that requires evaluation of environmental impacts associated with a project before it can be approved. A SEPA checklist is completed if required by Ecology (typically only if some state permit is needed). An EA under NEPA may substitute for the SEPA checklist. Ecology will determine if a State EIS is required or will issue a determination of nonsignificance.

EVALUATION: A SEPA checklist may be required for this action-although the Washington State Department of Ecology was a co-author of DOE/EIS-0.00F Final Environmental Impact Statement for the Tank Waste Remediation System The Ecology Department may want to reevaluate the Canister Storage Building as it is earmarked to store Spent Nuclear Fuel High-Level Waste Canisters and Shipping Port Fuel The ROD for the above mentioned EIS may not take into account all of these fuel types

For additional information please contact M L Deffenbaugh - or B G Erlandson -

\section{DANGEROUS WASTE}

\section{Dangerous Waste Permit - WAC 173-303; 40 CFR 264, 265, 270}

Facilities that treat, store, or dispose of regulated dangerous waste must obtain the necessary dangerous waste permits. Whether a waste is a regulated dangerous waste must be determined in accordance with WAC 173-303-070 designation procedures. Existing Hanford Facility TSD units are obtaining permits in accordance with schedules and procedures identified in the Tri-Party Agreement. New Hanford Facility TSD units that are not identified in the Tri-Party Agreement will require development of a permitting plan to detail the strategies and schedules to be used for developing the necessary dangerous waste permits. This plan must be developed early in the project development phase. Strategies and schedules to be used for developing the necessary dangerous waste permits for new TSD units will need to be discussed with the appropriate regulatory agencies to gain their concurrence. 
EVALUATION: The vitrified HLW will contain RCRA regulated constituents and hazardous components. Per Wendy R. Dixon, Asst Manager Environment, Safety \& Health, Yucca Mountain Site Characterization Office. It is currently OCRWM's (Office of Civilian Radioactive Waste Management), policy that any spent nuclear fuel (SNF) or high-level radioactive waste (HLRW) that contains hazardous characteristics or is a listed waste as defined by RCRA may not be disposed of in the first NWPA-licensed repository.

According to Wendy, they have an EIS that is planned for completion in 1999 and it will reflect the same policy.

Also; Per DOC ID: E00000000-00811-1708-00001 Revision 02, "Waste Acceptance System Requirements Document". 3.2.3.1.1.14 Hazardous Waste Determination for HLW; DOE/OCRWM will only accept HLW that does not include components that are regulated as hazardous wastes under the Resource Conservation and Recovery Act (RCRA) for disposal in the first geologic repository. The following requirements implement the decision documented in a memorandum from RW to Secretary O'Leary on 06/22/95.

A. The producer shall determine and report to DOE/OCRWM the presence or absence of any hazardous waste listed in 40CFR261.31 through 261.33, in the waste or in any feed stream proposed for storage or disposal. Any RCRA-listed component in a waste shall require the Producer to petition EPA and receive exemption to delist the waste. [40CFR261.20(b)] [40CFR262.11] [CRD 3.3.11.G]

LMHC efforts should be focused on assuring that the privatization vendor produces a waste form which is acceptable to OCRWM. If that waste is deemed non-hazardous and acceptable to them, then there will be no need to permit the CSB.

Some other DOE sites (West Valley and Savannah River), have delisted their high-level waste in preparation for delivery to Yucca Mountain. It would be prudent for that effort to start here in concert with all of the other permitting work for this project.

For additional information, please contact M. L. Deffenbaugh (373-5399) or B. G. Erlandson (372-2678).

\section{Radiation Protection Standards - DOE Order 5400.5}

This DOE Order establishes standards and requirements that must be followed to protect members of the public and environment against undue risk from radiation. The general environmental protection program requirements are established in DOE Order 5400.1. 
HNF-SD-ENV-EE-002 Rev. 0

DOE Order 5400.1 requires that all DOE Sites prepare an environmental monitoring plan. DOE/RL 91-50, Environmental Monitoring Plan, includes DOE/EH-0173T, Environmental Regulatory Guide for Radiological Effluent Monitoring and Environmental Surveillance, which provides specific guidance regarding environmental monitoring activities.

EVALUATION: A monitoring plan should be developed for the facility.

For additional information, please call M. L. Deffenbaugh (373-5399), or B. G.

Erlandson (373-3678).

\section{ALL AIR EMISSIONS}

\section{Air Operating Permit - WAC 173-401}

WAC 173-401 establishes the elements of a comprehensive Washington State air operating permit program consistent with the requirements of Title $\mathrm{V}$ of the Federal clean Air Act. A sitewide permit is required for the Hanford facilities. This permit will address both radioactive and nonradioactive airborne emissions from all emission units that are above the listed threshold but are not limited to, criteria pollutants and hazardous air pollutants (including radionuclides). In this regulation, Ecology also has established thresholds for regulated pollutants below which emissions would be considered insignificant for the purposes of the operating permit program. Ecology has proposed new sections to Chapter 173-401 to define IEUs and activities. Categorically exempt units/activities may be omitted from the permit. Other IEU items/activities must be listed on the permit, but are exempt from the administrative requirements of the permit.

The permit will establish emission limits and conditions of operation restrictions for major sources on the Hanford Site. If a new NOC is required and an emission unit becomes operational after the permit is issued by the state, a permit revision will be required within 12 months after commencing operation. This application for modification shall be prepared in accordance with WAC 173-401-725. The NOC and permit modification can be sought concurrently. Any NOC application and associated documentation should be retained for future use in the Air Emissions Inventory that will be supporting the preparation of the title V Air Operating Permit application. 
EVALUATION: Per internal correspondence \# 93-RPB-079; From J. D. Bauer (RL), to D. B. Jansen (Ecology); "The sealed canisters will provide the primary confinement of the hazardous vitrified material. The vitrified material will be in a solid borosilicate glass form, and the filled canisters will have been evacuated, sealed, decontaminated and surveyed before being placed in the CSB. No regulated pollutants will be released from the sealed canisters."

Per DOH/RL/WHC/PNL Meeting Minutes \# 88300-92-122; "Mr. Conklin stated that DOH agrees that the CSB will not be a source of emissions subject to construction approval, so long as the sealed canisters are verified to have no surface contamination before transfer from the Vitrification Building."

Conclusion; The CSB will not be a source of regulated emissions to the atmosphere. As a result, no requirement exists for permitting the CSB under the clean Air Act.

For additional information contact M. L. Deffenbaugh (373-5399), or B. G. Erlandson (372-2678).

\section{SOLID WASTE}

\section{Solid Waste Handling Facility Permit - WAC 173-304}

Solid waste TSD sites or facilities (i.e., landfills, land spreading, piles, surface impoundments, and recycling facilities) must obtain approval from Ecology via the comprehensive solid waste plan, and a permit from the jurisdictional health department before construction. All nonradioactive, nondangerous solid waste disposal at Hanford shall be in accordance with the substantive requirements of the Washington Administrative Code (WAC) 173-304, "Minimum Functional Standards for Solid Waste Handling." WAC 173351 does not apply to onsite DOE activities since the DOE is not a municipality.

EVALUATION: Any dangerous waste that is generated at the CSB during the normal operations of the facility will require management in a satellite accumulation area, or in accordance with the 90-day accumulation provisions of WAC 173-303-200. In addition, any suspect waste materials awaiting sampling/analysis results will need to be managed as dangerous waste until analysis is received. For additional information contact M. L. Deffenbaugh (373-5399), or B. G. Erlandson (372-2678). 


\section{HNF-SD-ENV-EE-002 Rev. 0}

\section{REFERENCES}

Calmus, 1996

Jacobs, 1996 